\title{
Development of the global atmospheric chemistry general circulation model BCC-GEOS-Chem v1.0: model description and evaluation
}

\author{
Xiao Lu ${ }^{1,2}$, Lin Zhang ${ }^{1}$, Tongwen $\mathrm{Wu}^{3}$, Michael S. Long ${ }^{2}$, Jun Wang ${ }^{4}$, Daniel J. Jacob ${ }^{2}$, Fang Zhang ${ }^{3}$, Jie Zhang ${ }^{3}$, \\ Sebastian D. Eastham ${ }^{5}$, Lu Hu${ }^{6}$, Lei $\mathrm{Zhu}^{2,7,8}$, Xiong Liu ${ }^{7}$, and Min Wei ${ }^{9}$ \\ ${ }^{1}$ Laboratory for Climate and Ocean-Atmosphere Sciences, Department of Atmospheric and Oceanic Sciences, \\ School of Physics, Peking University, Beijing 100871, China \\ ${ }^{2}$ School of Engineering and Applied Sciences, Harvard University, Cambridge, MA 02138, USA \\ ${ }^{3}$ Beijing Climate Center, China Meteorological Administration, Beijing 100081, China \\ ${ }^{4}$ Department of Chemical and Biochemical Engineering, and Center for Global and Regional Environmental Research, The \\ University of Iowa, Iowa City, IA 52242, USA \\ ${ }^{5}$ Laboratory for Aviation and the Environment, Massachusetts Institute of Technology, Cambridge, MA 02139, USA \\ ${ }^{6}$ Department of Chemistry and Biochemistry, University of Montana, Missoula, MT 59812, USA \\ ${ }^{7}$ Harvard-Smithsonian Center for Astrophysics, Cambridge, MA 02138, USA \\ ${ }^{8}$ School of Environmental Science and Engineering, Southern University of Science and Technology, \\ Shenzhen 518055, Guangdong, China \\ ${ }^{9}$ National Meteorological Information Center, China Meteorological Administration, Beijing 100871, China
}

Correspondence: Lin Zhang (zhanglg@pku.edu.cn) and Tongwen Wu (twwu@cma.gov.cn)

Received: 24 August 2019 - Discussion started: 28 October 2019

Revised: 10 July 2020 - Accepted: 22 July 2020 - Published: 31 August 2020

\begin{abstract}
Chemistry plays an indispensable role in investigations of the atmosphere; however, many climate models either ignore or greatly simplify atmospheric chemistry, limiting both their accuracy and their scope. We present the development and evaluation of the online global atmospheric chemical model BCC-GEOS-Chem v1.0, coupling the GEOS-Chem chemical transport model (CTM) as an atmospheric chemistry component in the Beijing Climate Center atmospheric general circulation model (BCCAGCM). The GEOS-Chem atmospheric chemistry component includes detailed tropospheric $\mathrm{HO}_{x}-\mathrm{NO}_{x}$-volatile organic compounds-ozone-bromine-aerosol chemistry and online dry and wet deposition schemes. We then demonstrate the new capabilities of BCC-GEOS-Chem v1.0 relative to the base BCC-AGCM model through a 3-year (2012-2014) simulation with anthropogenic emissions from the Community Emissions Data System (CEDS) used in the Coupled Model Intercomparison Project Phase 6 (CMIP6). The model captures well the spatial distributions and seasonal variations
\end{abstract}

in tropospheric ozone, with seasonal mean biases of 0.4 $2.2 \mathrm{ppbv}$ at $700-400 \mathrm{hPa}$ compared to satellite observations and within $10 \mathrm{ppbv}$ at the surface to $500 \mathrm{hPa}$ compared to global ozonesonde observations. The model has larger highozone biases over the tropics which we attribute to an overestimate of ozone chemical production. It underestimates ozone in the upper troposphere which is likely due either to the use of a simplified stratospheric ozone scheme or to biases in estimated stratosphere-troposphere exchange dynamics. The model diagnoses the global tropospheric ozone burden, $\mathrm{OH}$ concentration, and methane chemical lifetime to be $336 \mathrm{Tg}, 1.16 \times 10^{6}$ molecule $\mathrm{cm}^{-3}$, and 8.3 years, respectively, which is consistent with recent multimodel assessments. The spatiotemporal distributions of $\mathrm{NO}_{2}, \mathrm{CO}, \mathrm{SO}_{2}$, $\mathrm{CH}_{2} \mathrm{O}$, and aerosol optical depth are generally in agreement with satellite observations. The development of BCC-GEOSChem v1.0 represents an important step for the development of fully coupled earth system models (ESMs) in China. 


\section{Introduction}

Atmospheric chemistry plays an indispensable role in the evolution of atmospheric gases and aerosols and is also an essential component of the climate system due to its active interactions with atmospheric physics and biogeochemistry on various spatiotemporal scales. Climate modulates the natural emissions, chemical kinetics, and transport of atmospheric gases and aerosols, while changes in many of these constituents alter the radiative budgets of the climate system and also influence the biosphere (Jacob and Winner, 2009; Fiore et al., 2012; Lu et al., 2019a). Climate-chemistry coupled models are indispensable tools to quantify climatechemistry interactions and to predict future air quality. However, coupling transport and chemistry of hundreds of chemical species on all spatiotemporal scales in climate system models (CSMs) poses a considerable challenge for model complexity and computational resources. Only 10 of the 39 CSMs in phase 5 of the Coupled Model Intercomparison Project (CMIP5) simulated atmospheric chemistry interactively (IPCC AR5, 2013). In the other models, including all the five Chinese CSMs, chemically active species were prescribed. The development of a climate-chemistry coupled model has been identified as a research frontier for atmospheric chemistry (National Research Council, 2012), and also a priority for CSM development particularly in China. An initiative to include the online simulation of atmospheric chemistry in CSMs, as an essential step toward building a climate-chemistry coupled model, was launched by the Beijing Climate Center (BCC) at the China Meteorological Administration (CMA) after CMIP5.

Here we present the development of the global atmospheric chemistry general circulation model BCC-GEOSChem v1.0, which enables online simulations of atmospheric chemistry in the BCC-CSM version 2 (BCC-CSM2). BCCGEOS-Chem is built on the coupling of the GEOS-Chem chemical module with the BCC atmospheric general circulation model (BCC-AGCM), the atmospheric component of the BCC-CSM2. BCC-CSM2 is a fully coupled global CSM in which the atmosphere, land, ocean, and sea-ice components interact with each other through the exchange of momentum, energy, water, and carbon (Wu et al., 2008, 2013, 2019). The earlier version of BCC-CSM (v1.1 and v1.1m) was enrolled in CMIP5 and has been widely applied to weather and climate research (e.g., Wu et al., 2013, 2014; Xin et al., 2013; Zhao and He, 2015). It has been recently updated to BCC-CSM2 and is being used in that configuration for the Coupled Model Intercomparison Project Phase 6 (CMIP6) (Wu et al., 2019). GEOS-Chem (http://geos-chem. org, last access: 10 July 2020), originally described by Bey et al. (2001), is a global three-dimensional chemical transport model (CTM) which includes detailed state-of-the-art gasaerosol chemistry and which is used by a large international community for a broad range of research on atmospheric chemistry, is continually updated with scientific innovations from users, is rigorously benchmarked, and is openly accessible on the cloud (Zhuang et al., 2019). The model is continually evaluated with atmospheric observations from its user community (e.g., Hu et al., 2017). The integration of BCCAGCM and GEOS-Chem for online simulations of global atmospheric chemistry will have attractive scientific and operational applications (e.g., sub-seasonal air quality prediction), and it also represents an important step for the development of fully coupled earth system models (ESMs) in China.

Until recently, the offline GEOS-Chem CTM relied exclusively on fixed latitude-longitude grids and was designed for shared-memory (OpenMP) parallelization. With such features, the GEOS-Chem CTM was not flexible enough to be coupled with BCC-CSM, which typically runs on spectral space (with adjustable options for the grid type and resolution dependent on the wave truncation number) and requires vast computational resources. The integration of GEOS-Chem chemical module into CSMs has been enabled by separating the module (which simulates all local processes including chemistry, deposition, and emissions) from the simulation of transport and making it operate on onedimensional (vertical) columns in a grid-independent manner (Long et al., 2015; Eastham et al., 2018). The GEOSChem chemical module can thus be coupled with a CSM on any grid, and the CSM simulation of dynamics then handles chemical transport. GEOS-Chem used as an online chemical module in CSMs shares the exact same code as the classic offline GEOS-Chem for local processes (chemistry, deposition, and emissions) (Long et al., 2015). This capability ensures that the scientific improvements of GEOS-Chem contributed by the worldwide research community can be conveniently incorporated into CSMs, allowing the chemistry of BCC-GEOS-Chem to be trackable to the latest GEOS-Chem version. Previous studies have demonstrated the success of coupling GEOS-Chem into the NASA GEOS-5 Earth system model and more recently the Weather Research and Forecasting (WRF) mesoscale meteorological model as an online atmospheric chemistry module (Long et al., 2015; Hu et al., 2018; Lin et al., 2020).

This paper presents the overview of the BCC-GEOSChem v1.0 model and evaluates the model simulation of present-day atmospheric chemistry. The model framework and its components are described in Sect. 2. We conducted a 3-year (2012-2014) model simulation to demonstrate the model's capability and for model evaluation. In Sect. 3, we compare simulated gases and aerosols with satellite and in situ observations and also diagnose the global tropospheric ozone burden and budget. Future plans for model development and summary are presented in Sect. 4. 


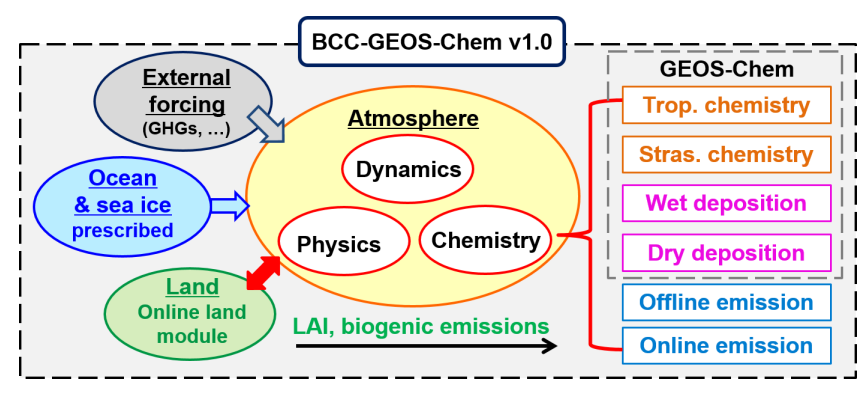

Figure 1. Schematic diagram of the BCC-GEOS-Chem v1.0 model framework.

\section{Development and description of the BCC-GEOS-Chem v1.0}

Figure 1 presents the framework of the BCC-GEOS-Chem v1.0. BCC-GEOS-Chem v1.0 includes interactive atmosphere (including dynamics, physics, and chemistry) and land modules, and other components such as ocean and sea ice are configured as boundary conditions for this version. The atmospheric dynamics and physics module (Sect. 2.1) and the land module (Sect. 2.2) come from the BCC-AGCM version 3 and the BCC Atmosphere and Vegetation Interaction Model version 2 (BCC-AVIM2), respectively. Atmosphere and land modules exchange the fluxes of momentum, energy, water, and carbon through the National Center for Atmospheric Research (NCAR) flux coupler version 5. Dynamic and physical parameters from both the atmosphere (e.g., radiation, temperature, and wind) and the land (e.g., surface stress and leaf area index) modules are then used to drive the GEOS-Chem chemistry (Sect. 2.3) and deposition (Sect. 2.4) of atmospheric gases and aerosols. Anthropogenic and biomass burning emissions are from the inventories used for the CMIP6 (Sect. 2.5.1). A number of climate-sensitive natural emissions such as biogenic and lightning emissions are calculated online in the model (Sect. 2.5.2). Boundary conditions, external forcing, and experiment design are described in Sect. 2.6.

\subsection{The atmospheric model BCC-AGCM3}

BCC-AGCM3 is a global atmospheric spectral model. It has adjustable horizontal resolution and 26 vertical hybrid layers extending from the surface to $2.914 \mathrm{hPa}$. In this study we use the default horizontal spectral resolution of T42 (approximately $2.8^{\circ}$ latitude $\times 2.8^{\circ}$ longitude). The dynamical core and physical processes of the BCC-AGCM3 have been described comprehensively in $\mathrm{Wu}$ et al. $(2008,2010)$ with recent updates documented in $\mathrm{Wu}$ et al. $(2012,2019)$. Wu et al. (2019) showed that the BCC-CSM2 (BCC-AGCM3 as the atmospheric model) captured well the global patterns of temperature, precipitation, and atmospheric energy budget. BCC-CSM2 also showed significant improvements in reproducing the historical changes in global mean surface temper- ature from the 1850s and climate variabilities such the QuasiBiennial Oscillation (QBO) and the El Niño-Southern Oscillation (ENSO) compared with its previous version BCCCSM1.1m (Wu et al., 2019). Here we present a brief summary of the main features in BCC-AGCM3.

The governing equations and physical processes (e.g., clouds, precipitation, radiative transfer, and turbulent mixing) of BCC-AGCM3 originated from the Eulerian dynamic framework of the Community Atmosphere Model (CAM3) (Collins et al., 2006), but substantial modifications have been incorporated. Wu et al. (2008) introduced a stratified reference of atmospheric temperature and surface pressure to the governing equations. In this way, prognostic temperature and surface pressure in the original governing equation can be derived from their prescribed reference plus the prognostic perturbations relative to the reference. Resolving algorithms (e.g., explicit and semi-implicit time difference schemes) were adapted accordingly. The modified dynamic framework reduced the truncation errors in the model, as well as the bias due to inhomogeneous vertical stratification, and therefore improved the descriptions of the pressure gradient force and the vertical temperature structure (Wu et al., 2008). BCC-AGCM3 also implements a new mass-flux cumulus scheme to parameterize deep convection (Wu, 2012). The revised deep convection parameterization by including the entrainment of environment air into the uplifting parcel better captured the realistic timing of intense precipitation (Wu, 2012) and the Madden-Julian Oscillation (MJO) (Wu et al., 2019). Other important updates of atmospheric physical processes in BCC-AGCM3 relative to CAM3 include a new dry adiabatic adjustment to conserve the potential temperature, a modified turbulent flux parameterization to involve the effect from waves and sea spray on ocean surface latent and sensible heat, a new scheme to diagnose cloud fraction, a revised cloud microphysics scheme to include the indirect effects of aerosol based on bulk aerosol mass, and modifications for radiative transfer and boundary layer parameterizations (Wu et al., 2010, 2014, 2019).

\subsection{The land model BCC-AVIM2}

BCC-AVIM2 is a comprehensive land surface model originating from the Atmospheric and Vegetation Interaction Model (AVIM) (Ji, 1995; Ji et al., 2008) which serves as the land component in BCC-CSM2. It includes three submodules: the biogeophysical module, plant ecophysiological module, and soil carbon-nitrogen dynamic module. The biogeophysical module simulates the transfer of energy, water, and carbon between the atmosphere, plant canopy, and soil. It has 10 soil layers and up to 5 snow layers. The ecophysiological module describes the ecophysiological activities, such as photosynthesis, respiration, turnover, and mortality of vegetation, and diagnoses the induced changes in biomass. The soil carbon-nitrogen dynamic module describes the biogeochemical process such as the conversion and decomposi- 
tion of soil organic carbon. The vegetation surface in BCCAVIM2 is divided into 15 plant functional types (PFTs), as shown in Table 1, and each grid cell contains up to four PFTs. Wu et al. (2013) showed that the model captured well the spatial distributions, long-term trends, and interannual variability of global carbon sources and sinks compared to observations and other models. Recent improvements in BCCAVIM2, such as the introduction of a variable temperature threshold for the thawing/freezing of soil water and improved presentations of snow surface albedo and snow cover fraction, are described in Li et al. (2019). Biogenic emissions and dust mobilizations are also implemented in BCC-AVIM2 interactively with the atmosphere, as will be described later in Sect. 2.5.

\subsection{Atmospheric chemistry}

We implement in this study the GEOS-Chem v11-02b "Tropchem" mechanism as the atmospheric chemistry module of BCC-GEOS-Chem v1.0. As described in the introduction, GEOS-Chem used as an online chemical module in ESMs shares the exact same codes for local terms (chemistry, deposition, and emissions) as the classic offline GEOSChem. Here, we use the GEOS-Chem chemical module to process the chemistry and deposition in BCC-GEOS-Chem v1.0 and operate emissions separately in the model, as will be described in Sect. 2.5.

GEOS-Chem v11-02b Tropchem mechanism describes advanced and detailed $\mathrm{HO}_{x}-\mathrm{NO}_{x}$-volatile organic compounds (VOCs)-ozone-bromine-aerosol chemistry relevant to the troposphere (Mao et al., 2010, 2013; Parrella et al., 2012; Fischer et al., 2014; Marais et al., 2016). It includes 74 advected species (tracers) and 91 non-advected species (http://wiki.seas.harvard.edu/geos-chem/index.php/ Species_in_GEOS-Chem, last access: 10 July 2020). Tracer advection in BCC-GEOS-Chem v1.0 is performed using a semi-Lagrangian scheme (Williamson and Rasch, 1989), and the vertical diffusion within the boundary layer follows the parameterization of Holtslag and Boville (1993). Photolysis rates are calculated by the Fast-JX scheme (Bian and Prather, 2002). The simulation of sulfate-nitrate-ammonia (SNA) aerosol chemistry, four-size bins of mineral dust (radii of 0.1-1.0, 1.0-1.8, 1.8-3.0, and 3.0-6.0 $\mu \mathrm{m}$ ), and two types of sea salt aerosols (accumulating mode: $0.01-0.5 \mu \mathrm{m}$; coarse mode: $0.5-8.0 \mu \mathrm{m}$ ) follows Park et al. (2004), Fairlie et al. (2007), and Jaeglé et al. (2011). Aerosol and gasphase chemistry interact through heterogeneous chemistry on aerosol surface (Jacob, 2000; Evans and Jacob, 2005; Mao et al., 2013), aerosol effects on photolysis (Martin et al., 2003), and gas-aerosol partitioning of $\mathrm{NH}_{3}$ and $\mathrm{HNO}_{3}$ calculated by the ISORROPIA II thermodynamic module (Fountoukis and Nenes, 2007; Pye et al., 2009). Methane concentrations in the chemistry module are prescribed as uniform mixing ratios over four latitudinal bands $\left(90^{\circ}-30^{\circ} \mathrm{S}\right.$, $30^{\circ} \mathrm{S}-0^{\circ}, 0^{\circ}-30^{\circ} \mathrm{N}$, and $30^{\circ}-90^{\circ} \mathrm{N}$ ), with the year-specific annual mean concentrations given by surface measurements from the NOAA Global Monitoring Division. Stratospheric ozone is calculated by the linearized ozone parameterization (LINOZ) (McLinden et al., 2000) and is transported to the troposphere driven by the model wind fields.

\subsection{Dry and wet deposition}

Dry and wet deposition for both gas and aerosols are parameterized following GEOS-Chem algorithms. Dry deposition is calculated online based on the resistance-in-series scheme (Wesely, 1989). The scheme describes gaseous dry deposition by three separate processes, i.e., the turbulent transport in the aerodynamic layer, molecular diffusion through the quasi-laminar boundary layer, and uptake at the surface. Aerosol dry deposition further considers the gravitational settling of particles as described in Zhang et al. (2001). Variables needed for the dry deposition calculation, such as the friction velocity, Monin-Obukhov length, and leaf area index (LAI), are obtained from atmospheric dynamics/physics modules or the land module BCC-AVIM, based on which GEOS-Chem calculates the aerodynamic, boundary layer, and surface resistances. The impacts of some other shortterm land variables, such as stomatal conductance, on dry deposition are not included yet. We have also reconciled the land use types (LUTs) used in dry deposition with those used in BCC-AVIM following Geddes et al. (2016) and Zhao et al. (2017). The LUTs from BCC-AVIM are mapped directly onto the 11 deposition surface types used in GEOS-Chem, as shown in Table 1. Dry deposition velocity is calculated as the weighted average over all LUTs in each grid box.

Wet deposition of aerosols and soluble gases by precipitation in BCC-GEOS-Chem v1.0 includes the scavenging in convective updrafts, in-cloud rainout, and below-cloud washout (Liu et al., 2001). Following the implementation of GEOS-Chem chemical module to GEOS-5 ESM (Hu et al., 2018), the convective transport of chemical tracers and scavenging in the updrafts in BCC-GEOS-Chem v1.0 is performed using the GEOS-Chem convection scheme but with convection variables diagnosed from BCC-AGCM. This takes advantage of the existing capability of the GEOS-Chem scheme to describe gas and aerosol scavenging (Liu et al., 2001; Amos et al., 2012).

\subsection{Emissions}

\subsubsection{Offline emissions}

Historical anthropogenic emissions used in this study are mostly obtained from the Community Emissions Data System (CEDS) emission inventory (Hosely et al., 2017). CEDS is an updated global emission inventory which provides sectoral, gridded, and monthly emissions of reactive gases and aerosols from 1750 to 2014 for use in the CMIP6 experiment (Eyring et al., 2016; Hosely et al., 2018). Here we use 
Table 1. Mapping of land use types (LUTs) used in BCC-GEOS-Chem v1.0 to the Wesely deposition surfaces for deposition. Also shown are the roughness heights $\left(Z_{o}\right)$ for each LUT.

\begin{tabular}{lllr}
\hline & BCC-AVIM & $\begin{array}{l}\text { GEOS-Chem LUT } \\
\text { for dry deposition }\end{array}$ & $\begin{array}{r}Z_{o} \\
(\mathrm{~m})\end{array}$ \\
\hline 0 & BUT & Desert & 0.001 \\
1 & Needleleaf evergreen temperate tree & Coniferous forest & 1 \\
2 & Needleleaf evergreen boreal tree & Coniferous forest & 1 \\
3 & Needleleaf deciduous boreal tree & Coniferous forest & 1 \\
4 & Broadleaf evergreen tropical tree & Amazon forest & 1 \\
5 & Broadleaf evergreen temperate tree & Deciduous forest & 1 \\
6 & Broadleaf deciduous tropical tree & Deciduous forest & 1 \\
7 & Broadleaf deciduous temperate tree & Deciduous forest & 1 \\
8 & Broadleaf deciduous boreal tree & Deciduous forest & 1 \\
9 & Broadleaf evergreen shrub & Shrub/grassland & 0.01 \\
10 & Broadleaf deciduous temperate shrub & Shrub/grassland & 0.01 \\
11 & Broadleaf deciduous boreal shrub & Shrub/grassland & 0.01 \\
12 & C 3 arctic grass & Tundra & 0.002 \\
13 & C non-arctic grass & Tundra & 0.01 \\
14 & C 4 grass & Tundra & 0.01 \\
15 & Crop & Agricultural land & 0.1 \\
16 & Wheat & Agricultural land & 0.1 \\
17 & Ocean & Water & 0.001 \\
18 & Glacier & Snow/ice & 0.0001 \\
19 & Lake & Water & 0.001 \\
20 & Wetland & Wetland & 0.05 \\
21 & Urban & Urban & 2.5 \\
\hline & & &
\end{tabular}

the CEDS anthropogenic emissions of $\mathrm{NO}_{x}, \mathrm{CO}, \mathrm{SO}_{2}, \mathrm{NH}_{3}$, non-methane volatile organic compounds (NMVOCs), and carbonaceous aerosols (black carbon, $\mathrm{BC}$, and organic carbon, OC) (Table 2). We also include three-dimensional aircraft emissions of several gases and aerosols in the model. The historical global biomass burning emission inventory is obtained from van Marle et al. (2017) which is also used for the CMIP6 experiment. We also incorporate emissions from the Atmospheric Chemistry and Climate Model Intercomparison Project (ACCMIP) inventory (http://accent.aero.jussieu. fr/ACCMIP.php, last access: 14 June 2020; Lamarque et al., 2010) and from Wu et al. (2020) for emissions not included in the CEDS dataset. These mainly apply to oceanic emissions, soil $\mathrm{NO}_{x}$ emissions, and volcanic $\mathrm{SO}_{2}$ emissions. Several sources (e.g., oceanic acetaldehyde emissions; Millet et al., 2010; Wang et al., 2019) have not yet been included in this model version.

Table 2 lists the amount of annual total emissions of chemicals used in this study separated by emission sectors averaged over 2012-2014. Figure $2 \mathrm{a}$ and $\mathrm{b}$ show the spatial distributions of annual NO (not including lightning emissions which will be discussed below separately) and $\mathrm{CO}$ emissions. Global annual total emissions of NO (not including lightning emissions) and $\mathrm{CO}$ are 111.1 and $925.5 \mathrm{Tg} \mathrm{yr}^{-1}$, respectively. The global anthropogenic emissions are relatively flat in 2012-2014 (e.g., from 614.7 to $619.6 \mathrm{Tg} \mathrm{yr}^{-1}$ for CO), while the biomass burning emissions have much stronger in- terannual variability (e.g., varying from 209 to $256 \mathrm{Tg} \mathrm{yr}^{-1}$ for CO). As pointed out by Hosely et al. (2018), CEDS anthropogenic emissions are generally higher than previous inventories. For instance, the anthropogenic $\mathrm{NO}_{x}$ and $\mathrm{CO}$ emissions are, respectively, about $10 \%$ and $8 \%$ higher compared to CMIP5 emissions in the 1980-2000 period. This is likely due to the updates of emission factors and inclusion of new emission sectors (Hosely et al., 2018). Compared to CMIP5, biomass burning emissions used in CMIP6 for year 2000 conditions are about $20 \%$ and $30 \%$ lower for $\mathrm{CO}$ and OC, respectively, but are about $17 \%$ higher for $\mathrm{NO}_{x}$ (Fig. 13 in van Marle et al., 2017).

\subsubsection{Online emissions}

BCC-GEOS-Chem v1.0 includes a number of climatesensitive natural sources. Biogenic emissions of NMVOCs are calculated online using the Model of Gases and Aerosols (MEGAN) algorithm (Guenther et al., 2012) in the land module. MEGAN estimates biogenic emissions as a function of an emission factor at standard condition, a normalized emission activity factor relative to the standard condition, and a scaling ratio which accounts for canopy production and loss. The emission activity factor is further determined by surface or plant parameters such as leaf age and LAI diagnosed in BCC-AVIM, as well as meteorological variables such as radiation and temperature. The annual biogenic iso- 
Table 2. Global annual emissions used in the BCC-GEOS-Chem v1.0 categorized by sectors (in $\operatorname{Tg~yr}^{-1}$ ).

\begin{tabular}{|c|c|c|c|c|c|c|c|c|}
\hline Species & Anthropogenic & $\begin{array}{r}\text { Biomass } \\
\text { burning }\end{array}$ & Biogenic & Ocean & Soil & Aircraft & Others & Total \\
\hline NO & 91.5 & 6.4 & & & 11.2 & 2.0 & Lightning: 11.5 & 122.6 \\
\hline $\mathrm{CO}$ & 617.2 & 231.8 & 75.9 & & & 0.6 & & 925.5 \\
\hline $\operatorname{ALK} 4\left(\mathrm{C}_{4} \mathrm{H}_{10}\right)$ & 17.7 & 0.2 & 26.1 & & & & & 44.0 \\
\hline $\operatorname{ALK} 5\left(\mathrm{C}_{5} \mathrm{H}_{12}\right)$ & 21.4 & & & & & & & 21.4 \\
\hline $\operatorname{ALK} 6\left(\mathrm{C}_{6} \mathrm{H}_{14}\right)$ & 26.5 & & & & & & & 26.5 \\
\hline Acetone $\left(\mathrm{CH}_{3} \mathrm{COCH}_{3}\right)$ & 1.1 & 3.1 & 19.2 & 9.9 & & & & 33.3 \\
\hline ALD2 $\left(\mathrm{CH}_{3} \mathrm{CHO}\right)$ & 1.2 & 2.4 & & & & & & 3.6 \\
\hline ISOP & & & 410.0 & & & & & 410.0 \\
\hline $\mathrm{C}_{2} \mathrm{H}_{4}$ & 5.9 & 3.2 & 7.5 & & & & & 16.6 \\
\hline $\operatorname{PRPE}\left(\mathrm{C}_{3} \mathrm{H}_{6}\right)$ & 3.6 & 2.5 & 10.7 & & & & & 16.8 \\
\hline $\mathrm{C}_{3} \mathrm{H}_{8}$ & 6.7 & 0.5 & & & & & & 7.2 \\
\hline $\mathrm{CH}_{2} \mathrm{O}$ & 2.5 & 3.2 & & & & & & 5.7 \\
\hline $\mathrm{C}_{2} \mathrm{H}_{6}$ & 6.6 & 2.7 & & & & & & 9.3 \\
\hline $\operatorname{BENZ}\left(\mathrm{C}_{6} \mathrm{H}_{6}\right)$ & 6.7 & & & & & & & 6.7 \\
\hline $\operatorname{TOLU}\left(\mathrm{C}_{7} \mathrm{H}_{8}\right)$ & 7.8 & & & & & & & 7.8 \\
\hline $\mathrm{XYLE}\left(\mathrm{C}_{8} \mathrm{H}_{10}\right)$ & 7.5 & & & & & & & 7.5 \\
\hline $\mathrm{SO}_{2}$ & 112.5 & 1.7 & & & & 0.3 & Volcano: 9.2 & 123.7 \\
\hline $\mathrm{NH}_{3}$ & 60.1 & 2.9 & & 8.2 & 2.4 & & & 73.6 \\
\hline DMS & & & & 27.4 & & & & 27.6 \\
\hline $\mathrm{BC}$ & 7.9 & 1.3 & & & & $<0.1$ & & 9.2 \\
\hline $\mathrm{OC}$ & 19.5 & 11.5 & & & & $<0.1$ & & 31.0 \\
\hline
\end{tabular}

prene emissions calculated in BCC-GEOS-Chem v1.0 are $410.0 \mathrm{Tg} \mathrm{yr}^{-1}$ averaged for the 2012-2014 period with a relatively small interannual variability (404.6 to $415.2 \mathrm{Tg} \mathrm{yr}^{-1}$ ). This is close to but lower than estimates from the literature (500-750 $\mathrm{Tg} \mathrm{yr}^{-1}$; Guenther et al., 2012). The model captures the hot spots of biogenic isoprene emissions in the tropical continents and the southeastern United States (Fig. 2c).

The parameterization of lightning NO emissions follows Price and Rind (1992). The model diagnoses the lightning flash frequency in deep convection as a function of the maximum cloud top height (CTH). Lightning NO production is then calculated as a function of lightning flash frequency, fraction of intracloud (IC) and cloud-to-ground (CG) lightning based on the cloud thickness, and the energy per flash (Price et al., 1997). Vertical distributions of lightning NO emissions in the column follow Ott et al. (2010). The model estimates global annual total lightning NO emissions of 10.9 to $12.2 \mathrm{Tg} \mathrm{NO} \mathrm{yr}^{-1}$ for $2012-2014$, in agreement with the best estimate of present-day emissions (10.7 \pm 6.4 $\mathrm{Tg} \mathrm{NO} \mathrm{yr}^{-1}$ as summarized in Schumann and Huntrieser, 2007). The emissions are centered near the tropics due to strong convection, as shown in Fig. 2d.

The model also includes wind-driven sea salt and mineral dust emissions. Emission fluxes of sea salt aerosols are dependent on the sea salt particle radius and proportional to the $10 \mathrm{~m}$ wind speed with a power of 3.41 following the empirical parameterization from Monahan et al. (1986) and Gong et al. (1997). Mineral dust emissions are determined by wind friction speed, soil moisture, and vegetation type following the Dust Entrainment and Deposition (DEAD) scheme as described by Zender et al. (2003). Figure $2 \mathrm{e}$ and $\mathrm{f}$ show the spatial distributions of sea salt and mineral dust emissions, with their annual total emissions of 3963 and $1347 \mathrm{Tg}$, respectively, being consistent with previous estimates from Jaeglé et al. (2011) and Fairlie et al. (2007).

\subsection{Boundary conditions, external forcing, and experiment design}

BCC-GEOS-Chem v1.0 is configured using prescribed ocean and sea ice as boundary conditions. Historical sea surface temperature and sea-ice extents are obtained from the Earth System Grid Federation (ESGF) (https://esgf-node. 1lnl.gov/search/input4mips/ last access: 2 June 2019). These prescribed datasets are also used in CMIP6 atmosphereonly simulations. External forcing data, including historical greenhouse gas concentrations $\left(\mathrm{CO}_{2}, \mathrm{CH}_{4}, \mathrm{~N}_{2} \mathrm{O}\right.$, CFCs) (Meinshausen et al., 2017), land use forcing, and solar forcing, are also accessed from the ESGF (https://esgf-node.llnl. gov/search/input4mips/, last access: 10 July 2020). BCCCSM2 has implemented the radiative transfer effects of greenhouse gases and aerosols, as well as the aerosolcloud interactions, based on bulk aerosol mass concentrations (Wu et al., 2019). Since BCC-CSM2 does not include interactive atmospheric chemistry, the calculation of radiative transfer and aerosol-cloud interactions is based on historical gridded ozone concentrations from CMIP5- and 

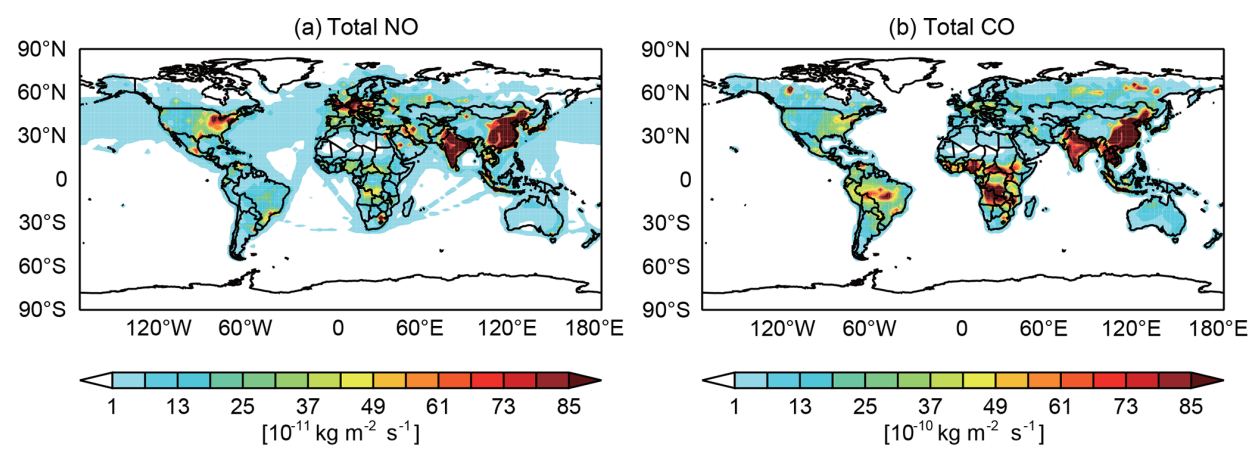

(c) Biogenic isoprene
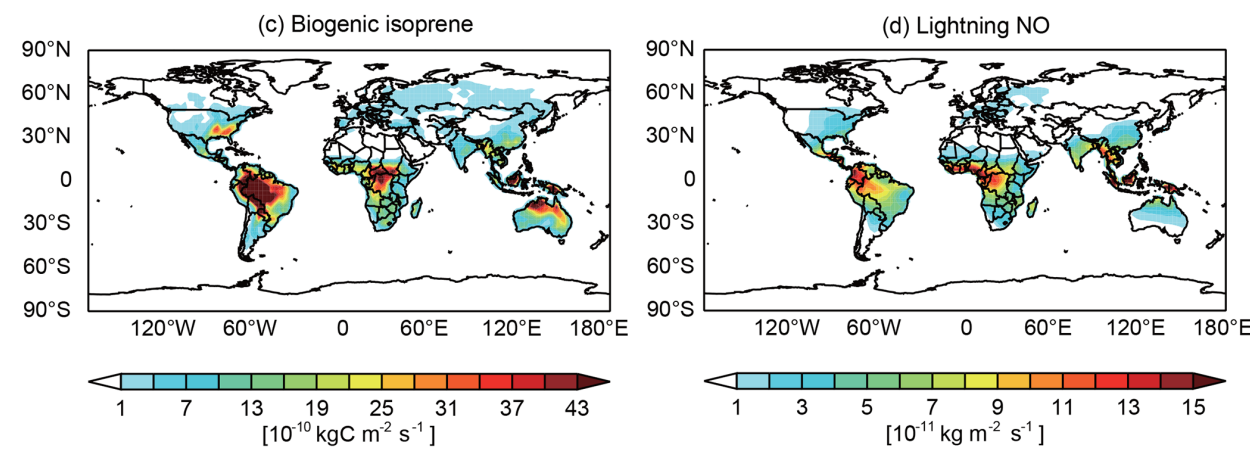

(e) Sea salt
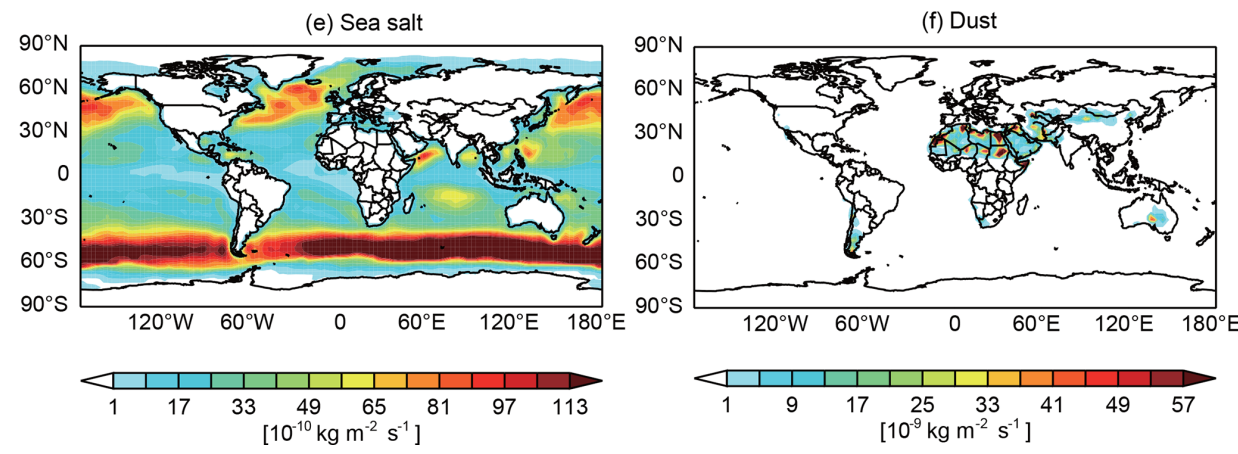

Figure 2. Spatial distributions of annual total emissions used in the study: (a) total NO emissions (not including lightning emissions), (b) total CO emissions, (c) biogenic isoprene emissions, (d) lightning NO emissions, (e) sea salt emissions (dry mass), and (f) mineral dust emissions.

CMIP6-recommended anthropogenic aerosol optical properties (Stevens et al., 2017). Here for BCC-GEOS-Chem v1.0, we follow BCC-CSM2 and use these prescribed ozone and aerosols rather than model online calculated values for feedback calculation. This is meant to focus on the modeling and evaluation of atmospheric chemistry in this work as the first step of the coupling. Interactive coupling of chemistry and climate through radiation and aerosol-cloud interactions will be considered in the next version of BCC-GEOS-Chem.

We conduct BCC-GEOS-Chem v1.0 simulations from 2011 to 2014. The initial conditions for atmospheric dynamics and physics in 2011 are obtained from the historical simulations (1850-2014) of BCC-CSM2 (Wu et al., 2019), and initial states of chemical tracers are obtained from the GEOSChem Unit Tester (http://wiki.seas.harvard.edu/geos-chem/ index.php/Unit_Tester_for_GEOS-Chem_12, last access: 2 June 2019). Model results for 2012-2014 are evaluated.

\section{Model evaluation}

\subsection{Observations used for model evaluation}

We use an ensemble of surface, ozonesonde, and satellite observations to evaluate the BCC-GEOS-Chem v1.0 simulation of present-day atmospheric chemistry (Table 3). Ozonesonde measurements are obtained from the World Ozone and Ultraviolet Radiation Data Centre (WOUDC; http://woudc.org/ data.php, last access: 2 June 2019) operated by the Meteorological Service of Canada. The network also includes sites from the Southern Hemisphere Additional Ozonesondes (SHADOZ; Thompson et al., 2003). To derive the monthly mean ozone profiles, only sites and months with more than three observations per month are considered, and simulated monthly mean ozone profiles are sampled over the corresponding model grids (Lu et al., 2019b). We further categorize the WOUDC observations into 10 regions following 


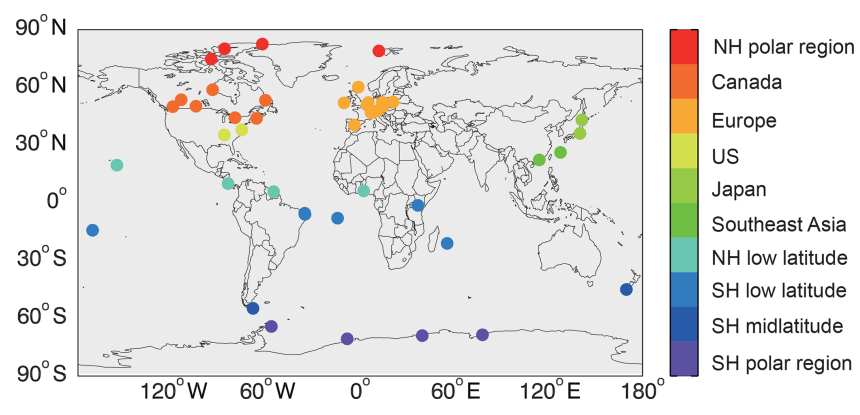

Figure 3. Locations of selected ozonesonde observations in 20122014 used in this study categorized by 10 regions.

Tilmes et al. (2012) and $\mathrm{Hu}$ et al. (2017) for model evaluation, as shown in Fig. 3. We also use the Tropospheric Ozone Assessment Report (TOAR) surface ozone database (Schultz et al., 2017a) that provides ozone metrics (e.g., monthly mean) for more than 9000 monitoring sites around the world from the 1970s to 2014 (Schultz et al., 2017b). Surface aerosol measurements (sulfate, nitrate, OC, BC) over the United States are obtained from the Interagency Monitoring of Protected Visual Environments (IMPROVE) network. These aerosol measurements are $24 \mathrm{~h}$ averages every $3 \mathrm{~d}$.

Satellite products from the NASA Earth Observing System (EOS) Aura's Ozone Monitoring Instrument (OMI) are also used. We use the OMI ozone profile (PROFOZ) with 24 layers extending from the surface to $60 \mathrm{~km}$ retrieved by Liu et al. $(2005,2010)$ based on the optimal estimation technique (Rodgers, 2000). The OMI PROFOZ dataset has been comprehensively validated through comparisons with ozonesondes (Zhang et al., 2010; Hu et al., 2017; Huang et al., 2017) and satellite products (Huang et al., 2018). We also use the OMI gridded monthly mean tropospheric nitrogen dioxide $\left(\mathrm{NO}_{2}\right)$ column (Krotkov et al., 2013), formaldehyde $\left(\mathrm{CH}_{2} \mathrm{O}\right)$ column (De Smedt et al., 2015), and planetary boundary layer (PBL) sulfur dioxide $\left(\mathrm{SO}_{2}\right)$ column (Krotkov et al., 2015). Other satellite observations include carbon monoxide (CO) observations from the Measurement of Pollution in the Troposphere (MOPITT) instrument (Deeter et al., 2017) and aerosol optical depth (AOD) at $550 \mathrm{~nm}$ from the Moderate Resolution Imaging Spectroradiometer (MODIS) (available at https://neo.sci.gsfc.nasa.gov/view. php?datasetId=MODAL2_M_AER_OD, last access: 2 June 2019). Satellite observations are further regridded to the model resolution for model evaluation except for the MODIS AOD dataset due to a large number of invalid measurements.

\subsection{Evaluation of tropospheric ozone with observations}

Figure 4 shows the spatial and seasonal distributions of midtropospheric ozone (700-400 hPa) from OMI satellite observations and BCC-GEOS-Chem v1.0 simulation averaged over 2012-2014, as well as their differences. We analyze ozone at $700-400 \mathrm{hPa}$ where OMI satellite has the peak sen- sitivity (Zhang et al., 2010). Model outputs are sampled along the OMI tracks and smoothed with OMI averaging kernels for a proper comparison with the observations (Zhang et al., 2010; Hu et al., 2017, 2018; Lu et al., 2018).

The model captures well the main features of tropospheric ozone distribution and seasonal variation. Both satellite observations and BCC-GEOS-Chem v1.0 model results show high mid-tropospheric ozone levels over the northern midlatitudes in boreal spring due to stronger stratospheric influences and in summer due to higher photochemical production and over the Atlantic and southern Africa during boreal autumn driven by strong biomass burning emissions (Fig. 2), lightning NOx, and dynamical processes (e.g., Sauvage et al., 2007). The spatial patterns of observed and simulated tropospheric ozone values are highly correlated with correlation coefficients $(r)$ of $0.79-0.93$. BCC-GEOS-Chem v1.0 shows small global seasonal mean biases of $0.4-2.2$ ppbv relative to OMI observations, which is comparable to the biases of 0.1-2.7 ppbv for G5NR-Chem (NASA GEOS-ESM with GEOS-Chem v10-01 as an online chemical module) in a similar period (Hu et al., 2018). We find that BCC-GEOSChem v1.0 tends to overestimate tropospheric ozone levels over tropical oceans by $3-12 \mathrm{ppbv}$ and underestimate ozone over the northern midlatitudes by 3-9 ppbv, similar to the patterns simulated by the classic GEOS-Chem and G5NR-Chem models (Hu et al., 2017, 2018).

Comparisons with global ozonesonde observations further demonstrate that BCC-GEOS-Chem v1.0 has no significant biases in the tropospheric ozone simulation. As shown in Fig. 5, the model reproduces well the observed annual mean ozone vertical structures, e.g., the slow increase in ozone with increasing altitude in the troposphere, and the sharp ozone gradient near and above the tropopause. Figure $6 \mathrm{com}-$ pares seasonal variations of ozone concentrations in different regions at three tropospheric levels $(800,500$, and $300 \mathrm{hPa})$. Overall, the model reproduces the ozone annual cycles driven by different chemical and dynamical processes. The model captures the springtime and summertime ozone peaks at the northern midlatitudes (Japan, United States, Europe, Canada) ( $r=0.53-0.94$ for different layers) but only fairly reproduces the annual ozone cycle in the Southern Hemisphere $(\mathrm{SH})$ and the tropics. Mean model biases at the three layers are mostly within $10 \mathrm{ppbv}$ with small low biases over the northern midlatitudes ( -6.0 to $-0.6 \mathrm{ppbv}$ ) and high biases over the tropics in the lower and middle troposphere (e.g., about $10 \mathrm{ppbv}$ at $800 \mathrm{hPa}$ over the $\mathrm{SH}$ tropics), which is consistent with the comparison with satellite observations (Fig. 4). We find that the model has large low ozone bias in the upper troposphere $(300 \mathrm{hPa})$ particularly over the northern polar regions $(\sim-30 \mathrm{ppbv})$. The underestimation extends to the stratosphere globally except for the extratropical Southern Hemisphere (Fig. 5). These negative model biases are likely due to the use of a simplified stratospheric ozone scheme and/or errors in the modeling dynamics of ozone exchange between the stratosphere and the troposphere, as 
Table 3. Observational datasets used for model evaluation.

\begin{tabular}{|c|c|c|c|c|}
\hline Species & Observation & Horizontal resolution & Vertical levels & Data sources or reference \\
\hline Ozone & WOUDC network & & Vertical profile & $\begin{array}{l}\text { http://woudc.org/data.php (last access: } \\
2 \text { June 2019) }\end{array}$ \\
\hline & TOAR dataset & & Surface & $\begin{array}{l}\text { Schultz et al. (2017a); https://doi.org/ } \\
\text { 10.1594/PANGAEA.876108 (last ac- } \\
\text { cess: } 2 \text { June 2019) }\end{array}$ \\
\hline & OMI satellite $\quad$ (Level 2) & $2^{\circ} \times 2.5^{\circ}$ & 24 layers & Liu et al. (2010) \\
\hline $\mathrm{CO}$ & MOPITT satellite (Level 3) & $1^{\circ} \times 1^{\circ}$ & $700 \mathrm{hPa}$ & $\begin{array}{l}\text { https://www2.acom.ucar.edu/mopitt } \\
\text { (last access: } 17 \text { June 2020); Deeter et } \\
\text { al. (2017) }\end{array}$ \\
\hline $\mathrm{NO}_{2}$ & OMI satellite (Level 3) & $0.25^{\circ} \times 0.25^{\circ}$ & Tropospheric column & $\begin{array}{l}\text { https://disc.gsfc.nasa.gov/datasets/ } \\
\text { OMNO2d_003/summary (last access: } \\
\text { 2 June 2019); Krotkov et al. (2019) }\end{array}$ \\
\hline $\mathrm{CH}_{2} \mathrm{O}$ & OMI satellite (Level 3) & $0.25^{\circ} \times 0.25^{\circ}$ & Tropospheric column & $\begin{array}{l}\text { http://h2co.aeronomie.be/ (last access: } \\
2 \text { June 2019); De Smedt et al. (2015) }\end{array}$ \\
\hline $\mathrm{SO}_{2}$ & OMI satellite (Level 3) & $0.25^{\circ} \times 0.25^{\circ}$ & Tropospheric column & $\begin{array}{l}\text { https://disc.gsfc.nasa.gov/datasets/ } \\
\text { OMSO2e_003/summary (last access: } \\
\text { 2 June 2019); Krotkov et al. (2015) }\end{array}$ \\
\hline AOD & MODIS & $1^{\circ} \times 1^{\circ}$ & Atmosphere & $\begin{array}{l}\text { https://neo.sci.gsfc.nasa.gov/view.php? } \\
\text { datasetId=MODAL2_M_AER_OD } \\
\text { (last access: } 2 \text { June 2019) }\end{array}$ \\
\hline $\begin{array}{l}\text { Aerosol } \\
\text { compo- } \\
\text { sition }\end{array}$ & IMPROVE network & & Surface & $\begin{array}{l}\text { Interagency Monitoring of Protected } \\
\text { Visual Environments (IMPROVE) } \\
\text { (http://vista.cira.colostate.edu/ } \\
\text { Improve/, last access: } 7 \text { July 2019) }\end{array}$ \\
\hline
\end{tabular}

will be discussed later, or the low model vertical resolution (26 layers).

Figure 7 compares the simulated ground-level ozone with more than $300 \mathrm{rural} /$ remote sites (defined by a number of metrics including population density and nighttime lights data; Schultz et al., 2017b) around the world from the TOAR database. We average all observations within the same model grid square for statistical analyses, a recommended way for evaluating coarse-resolution chemical models (Cooper et al., 2020). BCC-GEOS-Chem v1.0 captures the spatial and seasonal distributions of global ground-level ozone with $r$ ranging from 0.53 to $0.59(N=154)$. The annual mean model biases are $4.9 \mathrm{ppbv}(15 \%)$ for all observations with a larger high bias in the June-July-August period (11.0 ppbv, $32 \%$ ). The inclusion of urban and suburban sites slightly decreases the spatial correlations $(r=0.34-0.60, N=292)$ and enlarges the annual mean high bias (10.2 ppbv). We find again that the high biases are more prominent in the tropics (e.g., coastal sites in the western Pacific and Indonesia) and in summer. Although the above comparison is heavily weighted toward the United States, Europe, Japan, and South Korea due to the quantity of observations in these regions, our results demonstrate the overall good performance of BCC-GEOS-
Chem v1.0 in simulating ground-level ozone at least for rural and remote regions.

\subsection{Tropospheric ozone and $\mathrm{OH}$ budgets in BCC-GEOS-Chem v1.0}

We then diagnose the global tropospheric ozone burden and its driving terms (Table 4 and Fig. 8). BCC-GEOS-Chem v1.0 estimates the global tropospheric ozone burden to be 336.0 Tg averaged over 2012-2014. This is consistent with the results from the classic offline GEOS-Chem CTM and the G5NR-Chem $(\sim 350 \mathrm{Tg})$ with an earlier version (v1001) of GEOS-Chem as the chemical module (Hu et al., 2017, 2018), and it is also in agreement with the recent model assessments of 49 models (320-370 Tg; Young et al., 2018). We divide the global tropospheric ozone burden into different regions following Young et al. (2013), as shown in Fig. 8a and $b$. We find that the overall distributions of ozone burden are consistent with the ensemble of 15 models from the Atmospheric Chemistry and Climate Model Intercomparison Project (ACCMIP) (Young et al., 2013). The main discrepancy between BCC-GEOS-Chem v1.0 and ACCMIP occurs within $30^{\circ} \mathrm{S}-30^{\circ} \mathrm{N}$. ACCMIP results show that ozone over 

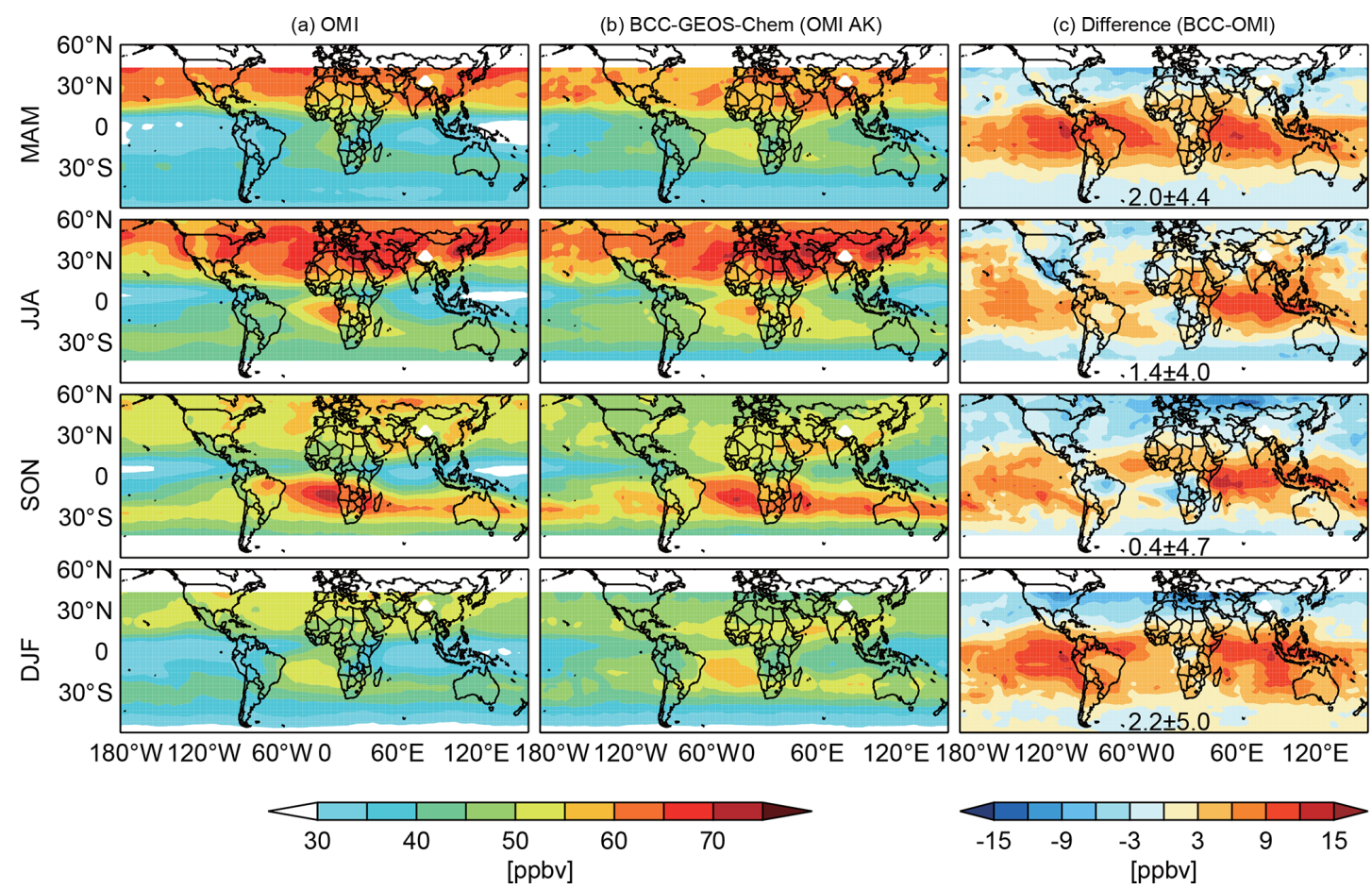

Figure 4. Spatial and seasonal distributions of tropospheric ozone at 700-400 $\mathrm{hPa}$ from (a) OMI satellite observations, (b) BCC-GEOSChem v1.0 model results (with OMI averaging kernels applied), and (c) differences between the two (model results minus observations) with the seasonal mean differences ( \pm standard deviations) shown inset. Values are 3-year averages over 2012-2014.

$30^{\circ} \mathrm{S}-30^{\circ} \mathrm{N}$ and below $250 \mathrm{hPa}$ accounts for $36.9 \%$ of the global tropospheric ozone burden, while BCC-GEOS-Chem v1.0 shows a higher proportion $(48.5 \%)$. While the ozone overestimation of BCC-GEOS-Chem v1.0 over $30^{\circ} \mathrm{S}-30^{\circ} \mathrm{N}$ is also seen from the comparisons to observations as discussed previously, the discrepancy between our results and the ACCMIP model ensemble mean is also likely due to the different simulation year (2000 conditions for ACCMIP versus 2012-2014 for BCC-GEOS-Chem v1.0). Zhang et al. (2016) showed that the equatorward redistribution of anthropogenic emissions significantly increased the global tropospheric ozone burden from 1980 to 2010 with the largest enhancements over the tropics. BCC-GEOS-Chem v1.0 underestimates the proportion of ozone burden in the upper troposphere $(5.1 \%-10.9 \%)$ compared to the ACCMIP results $(6.4 \%-15.2 \%)$, again likely reflecting the model limitation in simulating stratosphere ozone and/or its exchange with the troposphere.

We find that the global tropospheric mean $\mathrm{OH}$ concentration in BCC-GEOS-Chem $\mathrm{v} 1.0$ is $1.16 \times 10^{6}$ molecule $\mathrm{cm}^{-3}$, close to the offline GEOSChem v10-01 $\left(1.25 \times 10^{6}\right.$ molecule $\mathrm{cm}^{-3}$; Hu et al., 2018) and well within the range of 16 ACCMIP models $\left(1.11 \pm 0.16 \times 10^{6}\right.$ molecule $\mathrm{cm}^{-3}$; Naik et al., 2013). Figure $8 \mathrm{c}$ and $\mathrm{d}$ compare the distribution of simulated $\mathrm{OH}$ concentrations with the climatology derived from previous studies (Spivakovsky et al., 2000; Emmons et al., 2010).
We find that the model shows notable high bias in the lower troposphere (below $750 \mathrm{hPa}$ ) particularly in the tropics $(2.04$ to 2.45 molecule $\mathrm{cm}^{-3}$ in BCC-GEOS-Chem v1.0 compared to 1.44 to 1.52 molecule $\mathrm{cm}^{-3}$ in Spivakovsky et al., 2000). Discrepancies in modeling climate and concentrations of methane, ozone, $\mathrm{NO}_{x}$, and $\mathrm{CO}$ can all contribute to the $\mathrm{OH}$ bias in climate-chemistry models (Nicely et al., 2020). We calculate the methane chemical lifetime against $\mathrm{OH}$ loss to be 8.3 years in BCC-GEOS-Chem v1.0, which falls in the low end of the range reported from ACCMIP multimodel assessments (9.7 \pm 1.5 years) (Naik et al., 2013).

We now diagnose the budget of global tropospheric ozone in BCC-GEOS-Chem v1.0. Following the classic GEOSChem, BCC-GEOS-Chem v1.0 diagnoses the chemical production and loss of the odd oxygen family $\left(\mathrm{O}_{x}\right.$, including $\mathrm{O}_{3}$, $\mathrm{NO}_{2}, \mathrm{NO}_{y}$, several organic nitrates, and bromine species) to account for the rapid cycling among $\mathrm{O}_{x}$ constituents. Ozone accounts for more than $95 \%$ of the total $\mathrm{O}_{x}$ (Hu et al., 2017). The global annual ozone chemical production and loss are 5486 and $4983 \mathrm{Tg}$, respectively (Table 4); both are higher than the classic GEOS-Chem (Hu et al., 2017) and fall in the high quartile of multimodel assessments (Young et al., 2018). The high tropospheric ozone production is due at least in part to the high precursor emissions used in this study particularly for $\mathrm{NO}_{x}$ emissions. The model shows strong chemical production over northern midlatitude continents in summertime 


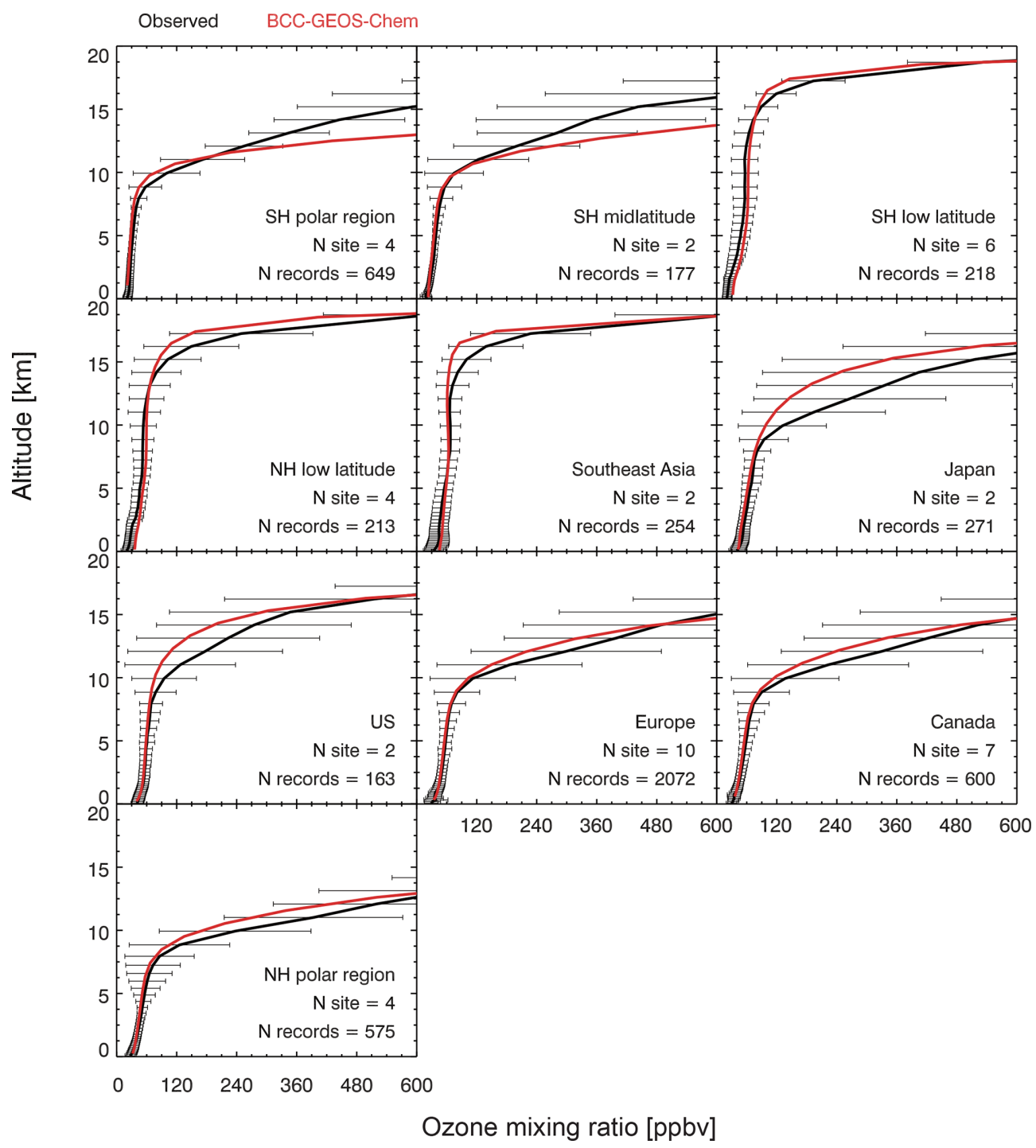

Figure 5. Comparisons of BCC-GEOS-Chem v1.0 simulated annual mean ozone vertical profiles to ozonesonde observations averaged over the 10 regions (Fig. 3) from south to north. Black horizontal bars are the standard deviations of observations. Numbers of available sites and records for each region in 2012-2014 are given inset.

and large chemical loss over the tropical oceans driven by high water vapor content (figure not shown).

The global annual mean ozone dry deposition flux diagnosed in BCC-GEOS-Chem v1.0 is $873 \mathrm{Tg}$ averaged over 2012-2014. It is consistent with recent reviews by Hardacre et al. (2015) and Young et al. (2018) (700-1500 Tg from 33 model estimates). Figure 9 presents the global ozone dry deposition velocity and flux for January and July 2012-2014. Both hemispheres show larger ozone dry deposition velocities in summer than winter due to stronger atmospheric turbulence and larger vegetation cover. A large ozone dry deposition velocity $\left(>0.5 \mathrm{~cm} \mathrm{~s}^{-1}\right)$ can be seen over the tropical continents, while over the oceans and glaciers ozone dry deposition is very weak.
We then diagnose the annual amount of ozone stratosphere-troposphere exchange (STE) of $370 \mathrm{Tg}$ as the residual of mass balance between tropospheric chemical production, chemical loss, and deposition as previous studies did (Lamarque et al., 2012; Hu et al., 2017). This value is lower than most of the other model estimates (400-680 Tg; Young et al., 2018). The low STE in BCC-GEOS-Chem v1.0 appears to be the main factor causing ozone underestimates in the upper troposphere, as seen above. This may reflect a number of model limitations, for example, the representation of stratospheric chemistry, inadequate STE due to model meteorology (e.g., biases in wind and tropopause), and the low model vertical resolution. Given the tropospheric ozone burden and its loss to chemistry and deposition, we derive the lifetime of tropospheric ozone of $20.9 \mathrm{~d}$, which 


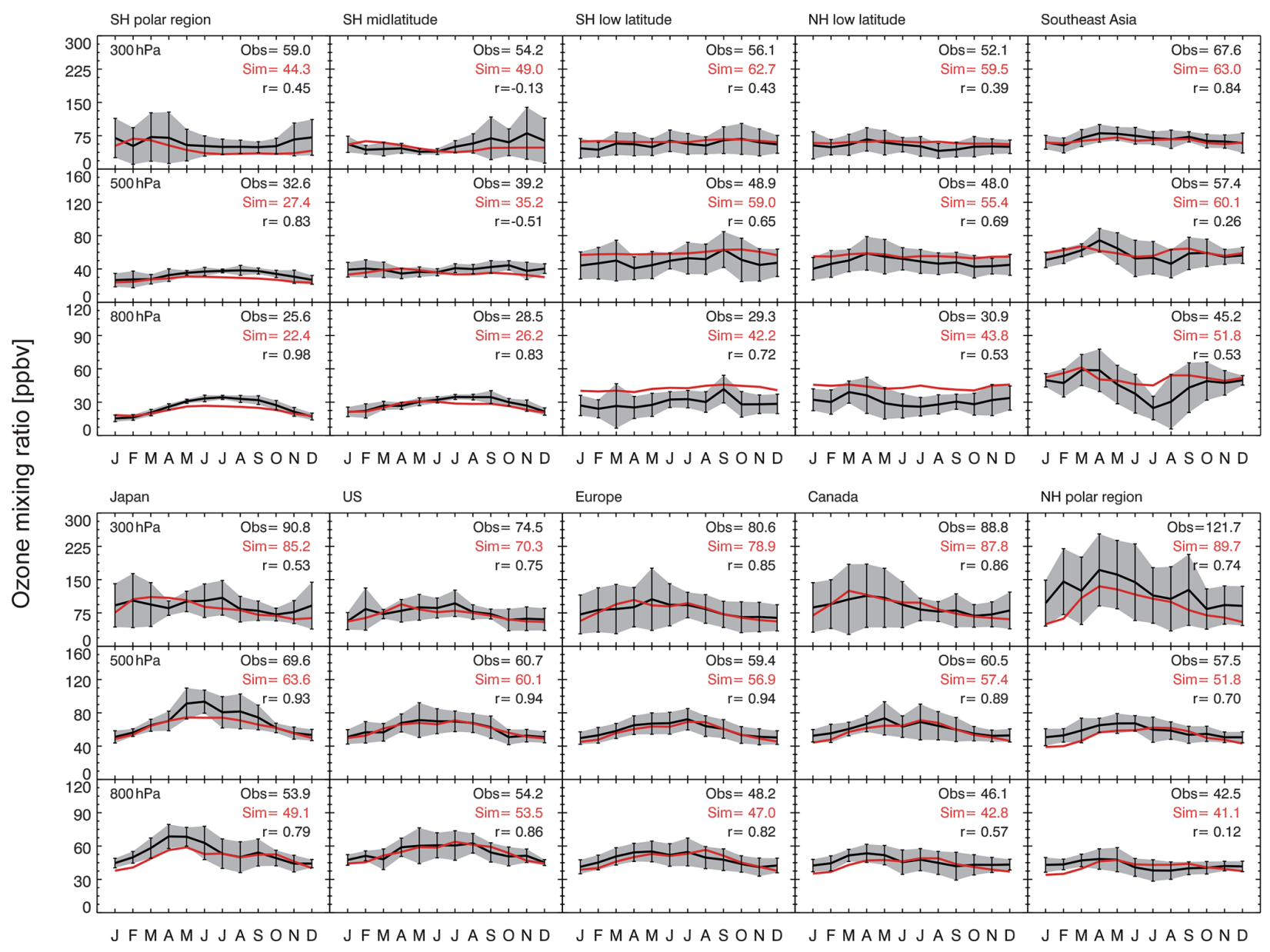

Figure 6. Seasonal variations of ozonesonde observed (black lines) and model simulated (red lines) ozone at three pressure levels (300, 500, and $800 \mathrm{hPa}$ ) averaged over the 10 regions (Fig.3). Vertical black bars and gray shadings are the standard deviations of observations. The annual means of observed and simulated ozone concentrations and their correlation coefficients are shown inset. Values are 3-year averages over 2012-2014.

Table 4. Global budget of tropospheric ozone diagnosed in BCC-GEOS-Chem v1.0 and comparison with other studies.

\begin{tabular}{|c|c|c|c|}
\hline Diagnostic term & $\begin{array}{r}\text { BCC-GEOS-Chem } \\
\text { (this study) }\end{array}$ & $\begin{array}{r}\text { Classic GEOS-Chem } \\
(\mathrm{Hu} \text { et al., 2017) }\end{array}$ & Other references \\
\hline Ozone burden (Tg) & 336 & 351 & Mean: 340 ; range: $250-410^{b}$ \\
\hline $\mathrm{O}_{x}$ chemical production $\left(\mathrm{Tg} \mathrm{yr}^{-1}\right)^{\mathrm{c}}$ & 5486 & 4960 & Mean: 4900; range: $3800-6900^{\mathrm{d}}$ \\
\hline $\mathrm{O}_{x}$ chemical loss $\left(\mathrm{Tg} \mathrm{yr}^{-1}\right)$ & 4983 & 4360 & Mean: 4600; range: $3300-6600^{\mathrm{e}}$ \\
\hline Dry deposition $\left(\mathrm{Tg} \mathrm{yr}^{-1}\right)$ & 873 & 908 & Mean: 1000 ; range: $700-1500^{f}$ \\
\hline STE $\left(\operatorname{Tg~yr}^{-1}\right)$ & $370^{\mathrm{g}}$ & $325^{\mathrm{g}}$ & Mean: 500 ; range: $180-920^{\mathrm{h}}$ \\
\hline Lifetime (days) & 20.9 & 24.2 & Mean: 22.3 ; range: $19.9-25.5^{\mathrm{i}}$ \\
\hline Global OH $\left(10^{6} \text { molecule } \mathrm{cm}^{-3}\right)^{\mathrm{j}}$ & 1.16 & 1.25 & Mean \pm SD: $1.11 \pm 0.16 ;$ range: $0.74-1.33^{\mathrm{k}}$ \\
\hline Methane chemical lifetime (years) & 8.27 & & Mean \pm SD: $9.7 \pm 1.5 ;$ range: $7.1-14.0^{\mathrm{k}}$ \\
\hline
\end{tabular}

${ }^{a}$ From Table 2 in Hu et al. (2017). The GEOS-Chem version is v10-01. ${ }^{b}$ From Fig. 3 in Young et al. (2018), 49 models for year 2000 conditions. ${ }^{c}$ Budget is for the odd oxygen family, including $\mathrm{O}_{3}, \mathrm{NO}_{2}, \mathrm{NO}_{y}$, several organic nitrates, and bromine species to account for the rapid cycling among $\mathrm{O}_{x}$ constituents. Ozone accounts for more than $95 \%$ of the total $\mathrm{O}_{x} .{ }^{\mathrm{d}}$ From Fig. 3 in Young et al. (2018), 33 models for year 2000 conditions. ${ }^{\mathrm{e}}$ From Fig. 3 in Young et al. (2018), 32 models for year 2000 conditions. ${ }^{\mathrm{f}}$ From Fig. 3 in Young et al. (2018), 33 models for year 2000 conditions. ${ }^{g}$ Estimated from the residual of mass balance between tropospheric chemical production, chemical loss, and deposition. ${ }^{\text {h }}$ From Fig. 3 in Young et al. (2018), 34 models for year 2000 conditions. ${ }^{i}$ From Table 2 in Young et al. (2013), 6 models for year 2000 conditions. ${ }^{j}$ Global annual mean air mass weighted $\mathrm{OH}$ concentration in the troposphere. ${ }^{k}$ From Table 1 in Naik et al. (2013), 16 models for year 2000 conditions. SD stands for standard deviation. 
(a) TOAR ozone observation
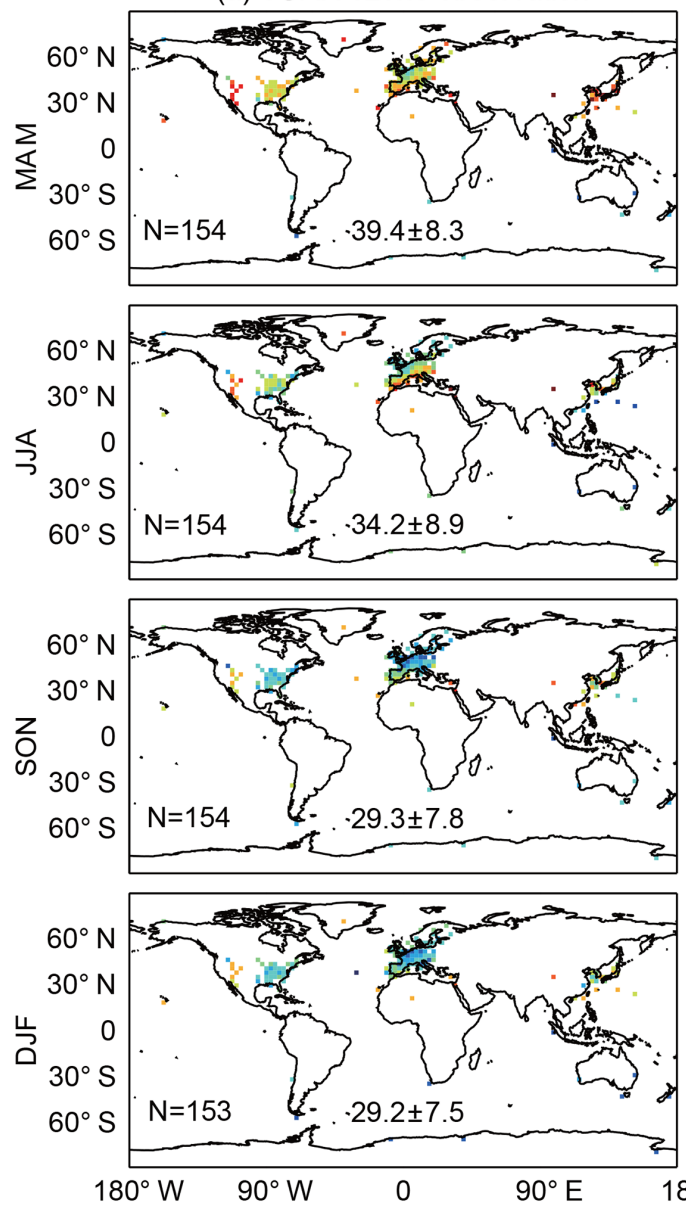
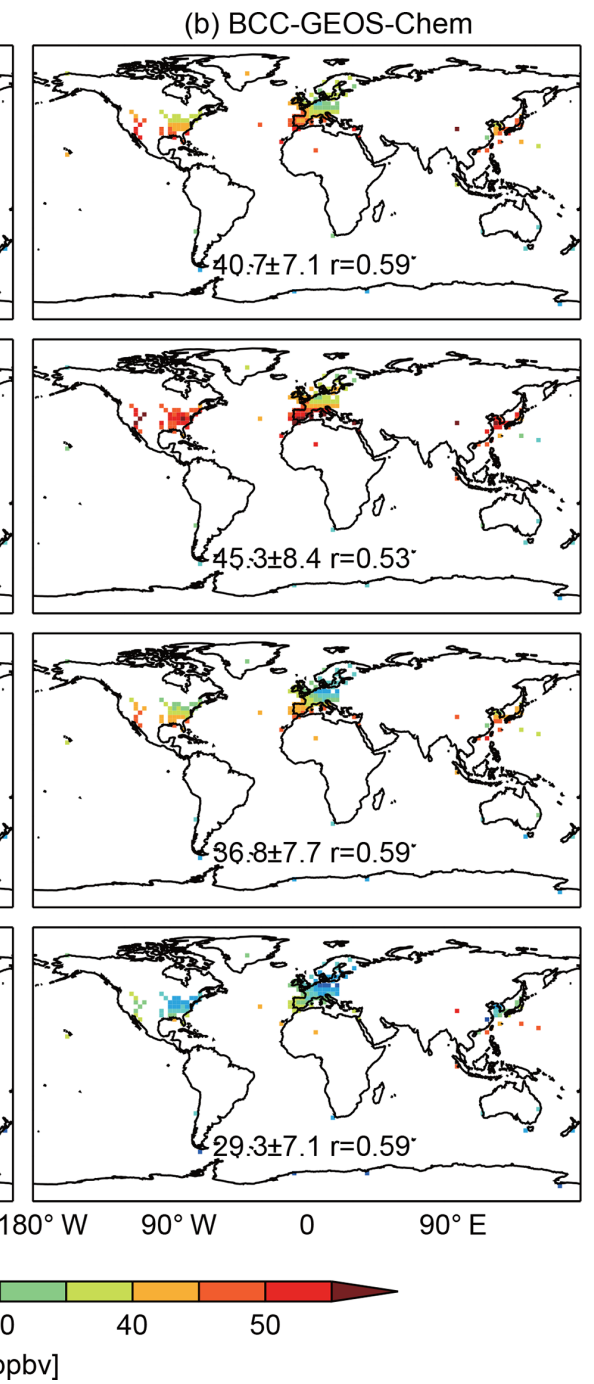

Figure 7. Spatial and seasonal distributions of observed and simulated surface ozone mixing ratios for 2012-2014. The model results (b) are compared to observations at rural/remote sites from the TOAR dataset (a). Observations are averaged to the same model grid. Seasonal mean values for observations and model results, their spatial correlation coefficients $(r)$, and the number of co-sampled grids $(N)$ are shown inset.

is consistent with the multimodel estimates (Young et al., 2013).

\subsection{Evaluation of other atmospheric constituents}

Figure 10 compares the spatial distributions of annual mean simulated $\mathrm{CO}, \mathrm{NO}_{2}, \mathrm{SO}_{2}$, and $\mathrm{CH}_{2} \mathrm{O}$ with satellite observations. We evaluate $\mathrm{CO}$ at $700 \mathrm{hPa}$ where the MOPITT satellite has generally high sensitivity (Emmons et al., 2004; Pfister et al., 2005) and apply averaging kernels to smooth the modeled CO. As shown in Fig. 10, BCC-GEOS-Chem v1.0 reproduces the high $\mathrm{CO}$ levels over the northern midlatitudes driven by higher anthropogenic sources and over central Africa driven by biomass burning emissions (spatial correlation coefficient $r=0.92$ ) with some overestimates. It also captures the observed hot spots of tropospheric $\mathrm{NO}_{2}(r=$
$0.87)$ and $\mathrm{PBL} \mathrm{SO}_{2}(r=0.32)$ columns over East Asia that generally follow the distribution of anthropogenic sources. The sharp land-ocean gradients for both tracers reflect their short chemical lifetime. We find low biases in the modeled $\mathrm{PBL} \mathrm{SO} \mathrm{S}_{2}$ especially over the volcanic eruption regions (e.g., central Africa) but high biases in the industrialized regions such as East Asia, a pattern consistent with previous comparisons between the OMI and GEOS-Chem PBL SO $\mathrm{S}_{2}$ columns, which may reflect inappropriate ship and volcanic emissions in the model (Lee et al., 2009) and/or the model bias in the PBL height. High levels of the tropospheric $\mathrm{CH}_{2} \mathrm{O}$ column are simulated over the Amazon, central Africa, tropical Asia, and the southeastern United States, typical regions where $\mathrm{CH}_{2} \mathrm{O}$ is oxidized from large biogenic emissions of volatile organic compounds (VOCs) $(r=0.67)$, but the model shows notable overestimates. Previous studies (Zhu et al., 2016, 
(a) ACCIMP ensemble from Young et al. (2013)

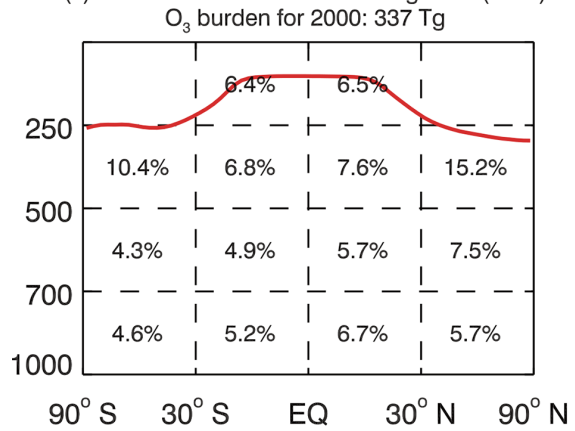

(c) Spivakovsky et al. (2000)

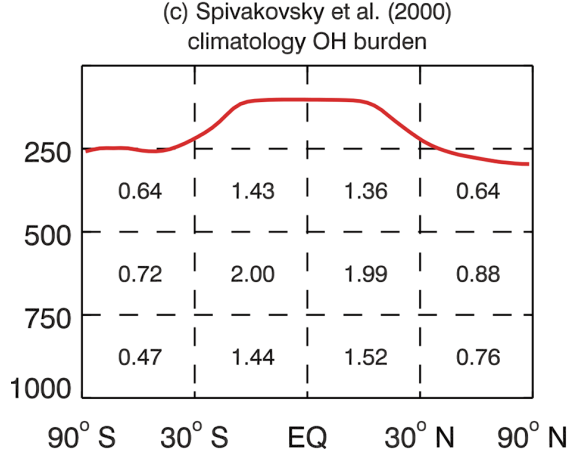

(b) BCC-GEOS-Chem

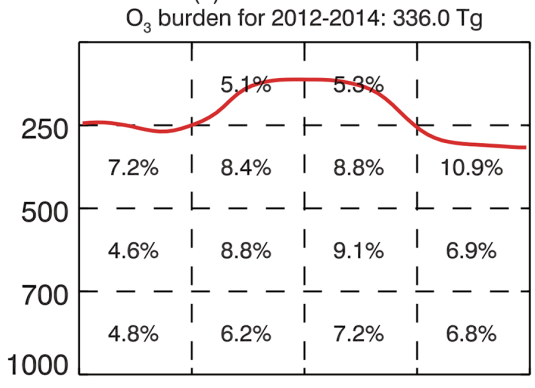

$90^{\circ} \mathrm{S} \quad 30^{\circ} \mathrm{S} \quad \mathrm{EQ} \quad 30^{\circ} \mathrm{N} \quad 90^{\circ} \mathrm{N}$

(d) BCC-GEOS-Chem

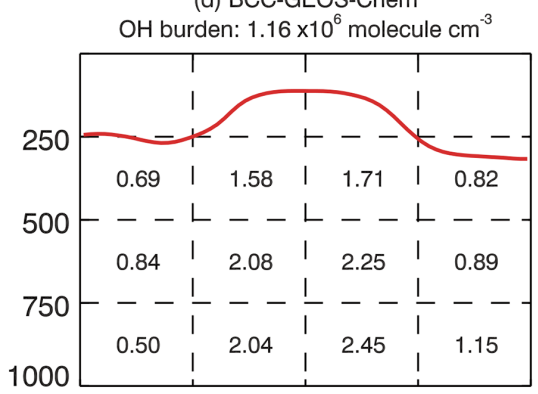

$90^{\circ} \mathrm{S} \quad 30^{\circ} \mathrm{S} \quad \mathrm{EQ} \quad 30^{\circ} \mathrm{N} \quad 90^{\circ} \mathrm{N}$

Figure 8. Zonal and vertical distributions of the tropospheric ozone burden and OH concentrations. For comparison, panel (a) shows tropospheric ozone burden in the year 2000 from Young et al. (2013) based on 15 ACCMIP models, and panel (c) shows the climatological tropospheric $\mathrm{OH}$ burden reported by Spivakovsky et al. (2000) and summarized by Emmons et al. (2010). Panel (b) and (d) show corresponding results from BCC-GEOS-Chem v1.0 averaged over 2012-2014. The red lines in (a) and (c) denote the tropopause derived from the National Centers for Environmental Prediction (NCEP) reanalysis, and those in (b) and (d) are from BCC-GEOS-Chem v1.0.

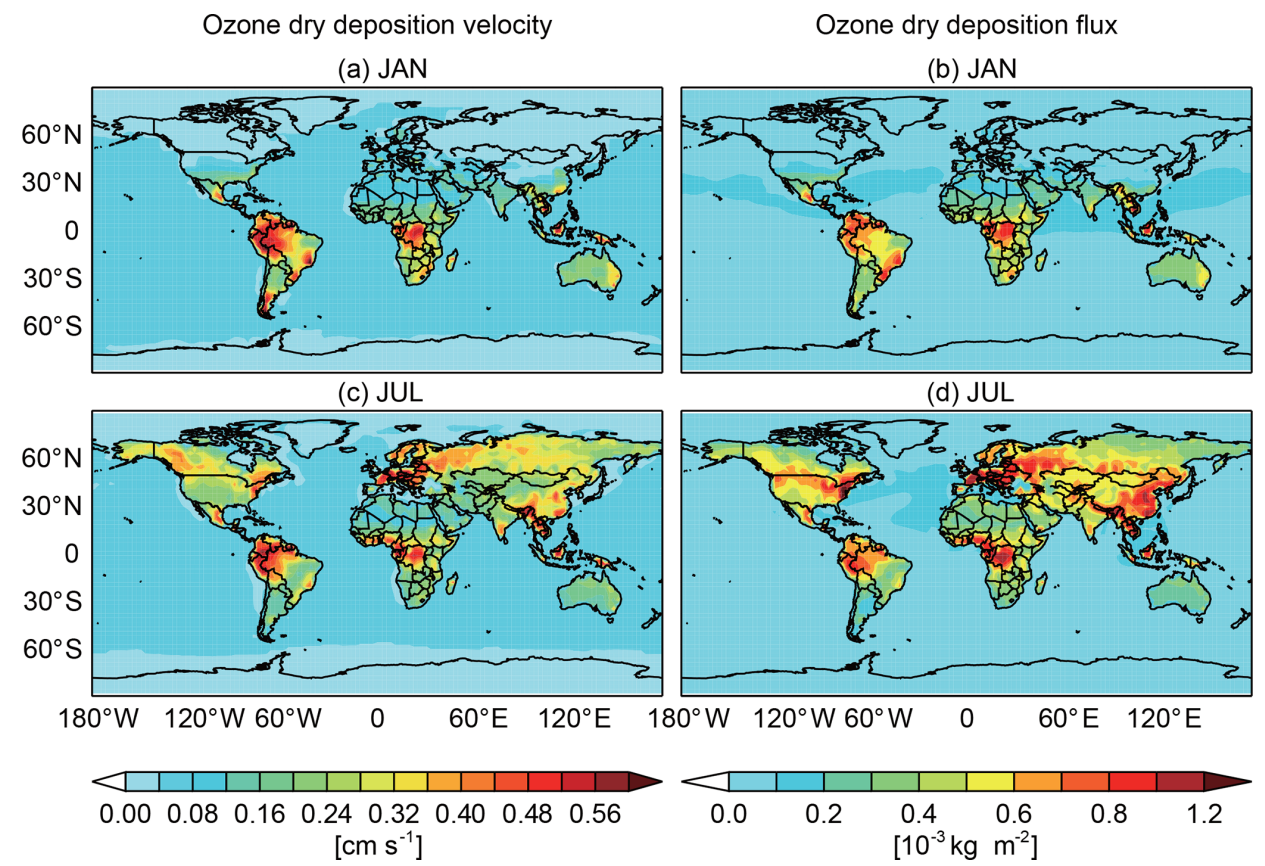

Figure 9. Monthly mean model diagnosed ozone deposition velocities $\left(\mathrm{cm} \mathrm{s}^{-1}\right)$ and fluxes $\left(\mathrm{kg} \mathrm{m}^{-2}\right)$ in January (a, b) and July (c, d). 

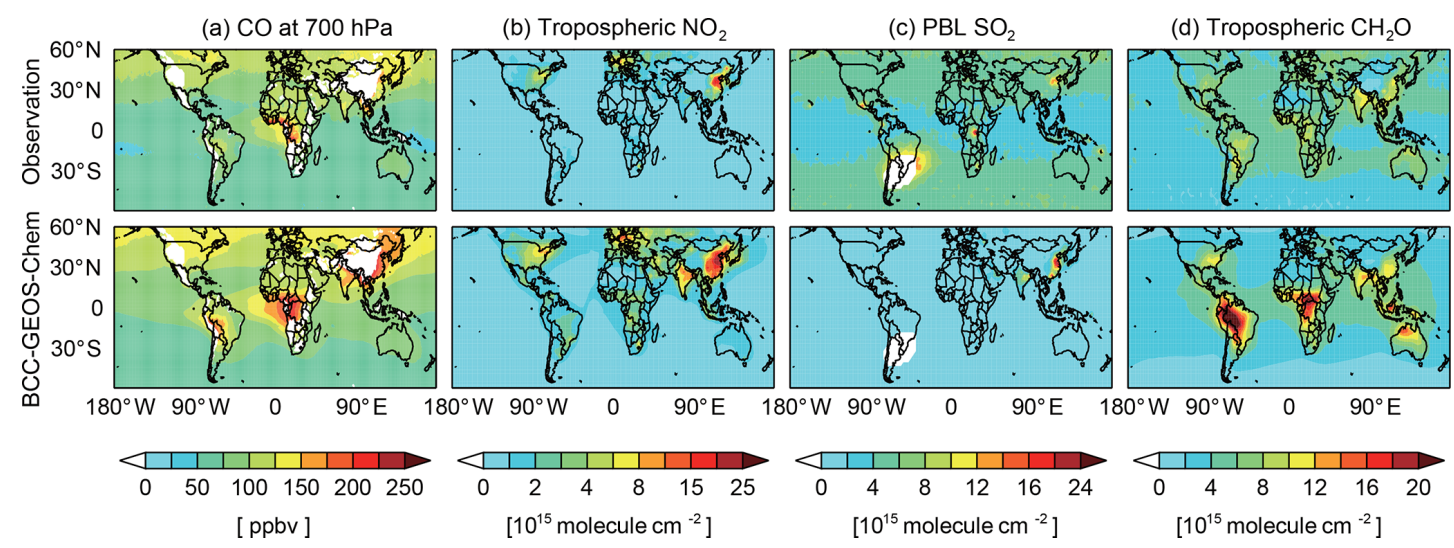

Figure 10. Spatial distributions of satellite observed (top panels) and model simulated (bottom panels) annual mean (a) $\mathrm{CO}$ mixing ratio at $700 \mathrm{hPa}$, (b) tropospheric $\mathrm{NO}_{2}$ column, (c) $\mathrm{SO}_{2}$ column in the planetary boundary layer, and (d) tropospheric $\mathrm{CH}_{2} \mathrm{O}$ column. Values are 3-year averages over 2012-2014.
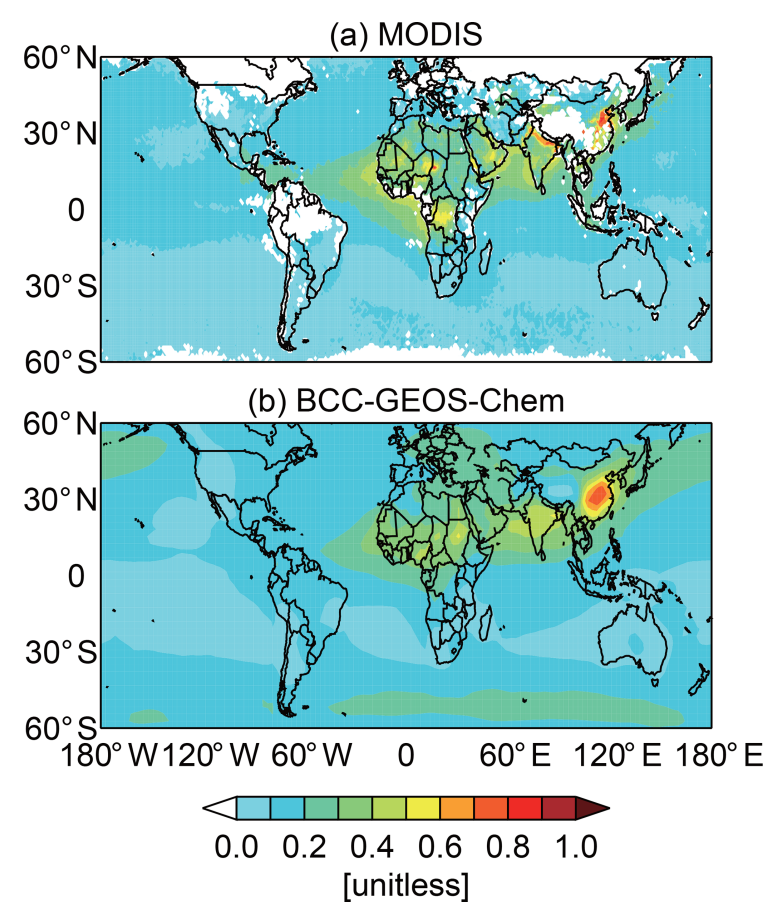

Figure 11. Spatial distributions of annual mean aerosol optical depth (AOD) at $550 \mathrm{~nm}$ from (a) MODIS satellite observations and (b) BCC-GEOS-Chem v1.0 averaged over 2012-2014.

2020) showed that satellite $\mathrm{CH}_{2} \mathrm{O}$ retrievals are low biased by $20 \%-51 \%$ compared to aircraft measurements, which would partly explain the model bias. Future assessments are required to correct the biases of these gaseous pollutants.

We evaluate model simulated AOD at $550 \mathrm{~nm}$ with the MODIS AOD observations in Fig. 11. High AOD values over East Asia due to high anthropogenic emissions and over Africa and the adjacent oceans due to dust emissions are shown in both MODIS observations and BCC-GEOS-Chem v1.0, although the model tends to underestimate the observed hot spots likely due to the coarse model resolution. Figure 12 further shows the comparison of simulated surface aerosol components (sulfate, nitrate, OC, and BC) with the observations from the IMPROVE network over the United States. The model fairly reproduces the spatial and seasonal patterns for all analyzed aerosol components, e.g., high sulfate and nitrate concentrations over the eastern United States. Among all the components, the simulation of sulfate in the United States shows best agreement with biases of $-10 \%-20 \%$ and spatial correlation coefficients of $0.76-0.87$ over model grids covering the measurement sites $(N=77)$. The model also captures the high summertime $\mathrm{OC}$ and $\mathrm{BC}$ concentrations in the midwestern United States driven by active wildfire activities ( $r=0.20-0.57$ for different seasons). However, the model shows high biases in wintertime nitrate in the eastern United States as found in previous GEOS-Chem evaluations (Zhang et al., 2012).

\section{Summary and future plans}

This study describes the framework and evaluation of the new global atmospheric chemistry general circulation model BCC-GEOS-Chem v1.0. The development of the BCCGEOS-Chem v1.0 takes advantage of the grid-independent structure of the GEOS-Chem chemical module, which allows the exact same GEOS-Chem chemistry and deposition algorithms to be performed on any external grid and supported by MPI (Message Passing Interface). BCC-GEOS-Chem v1.0 includes interactive atmospheric and land modules. It simulates the evolution of atmospheric chemical interactive constituents through a detailed mechanism of $\mathrm{HO}_{x}-\mathrm{NO}_{x}$ VOCs-ozone-bromine-aerosol tropospheric chemistry, as well as online wet and dry deposition schemes. The model also implements a number of climate-sensitive natural emissions such as biogenic VOCs and lightning NO. 

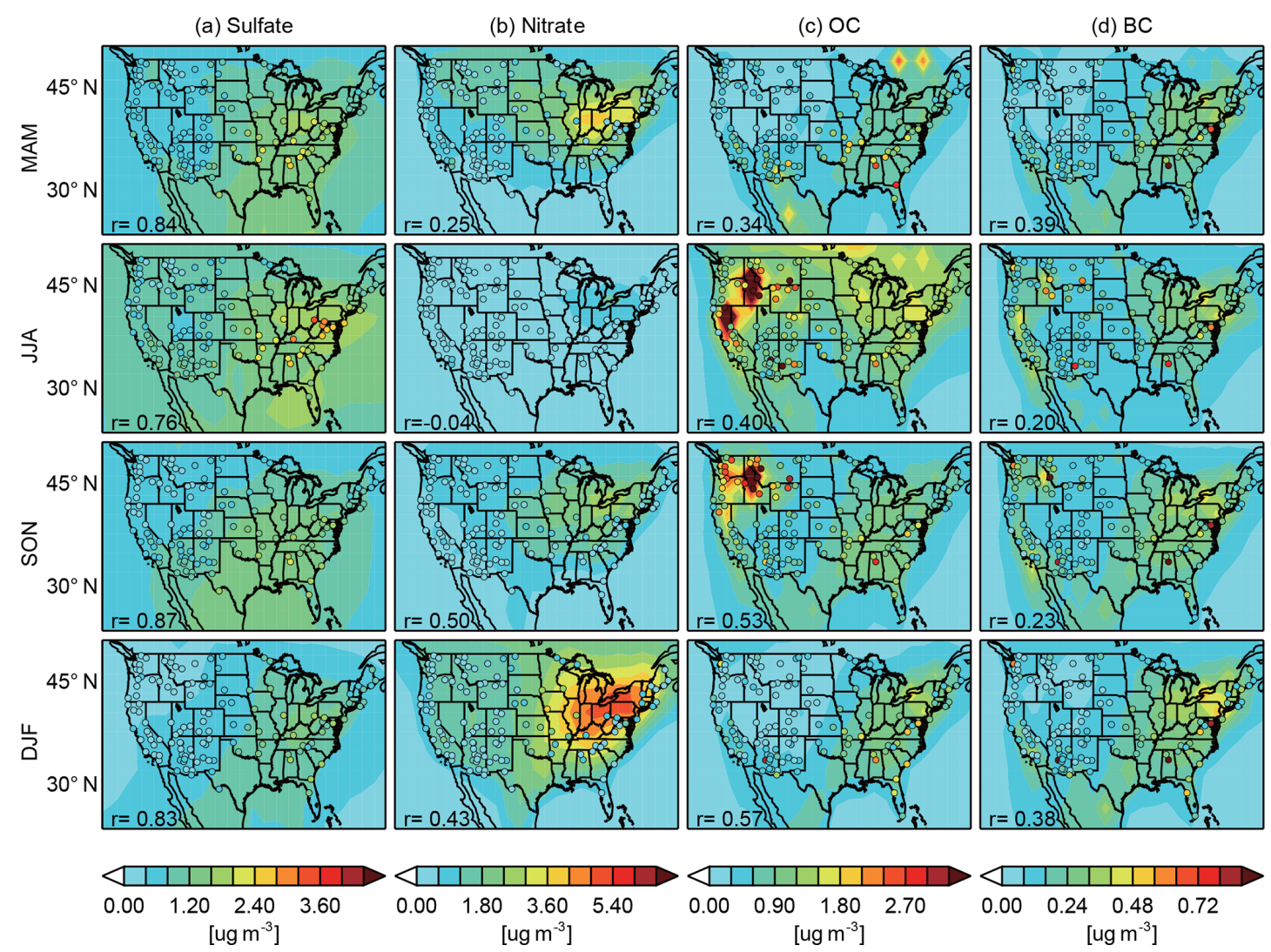

Figure 12. Spatial and seasonal distributions of simulated surface concentrations (contours) of (a) aerosol sulfate, (b) nitrate, (c) organic carbon, and (d) black carbon compared with observations from the United States IMPROVE network (circles) for 2012-2014. Correlation coefficients between observations and model results sampled at the site locations are shown inset.

We conduct a 3-year (2012-2014) model simulation with year-specific CMIP6 anthropogenic and biomass burning emissions. We evaluate the model with a focus on tropospheric ozone using surface, ozonesonde, and satellite observations. We show that BCC-GEOS-Chem v1.0 can capture well the spatial distributions $(r=0.79-0.93$ with OMI satellite observations of ozone at $700-400 \mathrm{hPa}$ ) and seasonal cycles of tropospheric ozone. The model shows no significant biases in the lower and middle tropospheric ozone compared to satellite observations $(0.4-2.2 \mathrm{ppbv}$ at 700 $400 \mathrm{hPa}$ ), ozonesonde (within $10 \mathrm{ppbv}$ at 800,500 , and $300 \mathrm{hPa}$ except for the polar upper troposphere), and surface measurements $(4.9 \mathrm{ppbv})$. We calculate a global tropospheric ozone burden of $336 \mathrm{Tg}^{-1}$ and $\mathrm{OH}$ burden of $1.16 \times 10^{6}$ molecule $\mathrm{cm}^{-3}$; both are well within the ranges reported by previous studies. Regionally, the model shows notable high biases in ozone over the tropics and low ozone biases in the upper troposphere. Model diagnostics show that BCC-GEOS-Chem v1.0 has higher tropospheric ozone chemical production and loss compared to the classic GEOSChem but still falls in the range of previous estimates. Comparisons of other air pollutants including $\mathrm{NO}_{2}, \mathrm{SO}_{2}, \mathrm{CO}$,
$\mathrm{CH}_{2} \mathrm{O}$, and aerosols show reasonable agreements with biases likely due to uncertainties in emissions.

The development of BCC-GEOS-Chem v1.0 for online atmospheric chemistry simulations represents an important step in the development of fully coupled earth system models in China. There are still several limitations in this version that should be addressed in future model development. The current version of BCC-GEOS-Chem does not include a full stratospheric chemistry mechanism, which is important for accurately modeling the evolution of ozone and its climate influences (Lu et al., 2019a). We plan to implement the unified tropospheric-stratospheric chemistry extension (UCX) (Eastham et al., 2014), which is now the "standard" mechanism for GEOS-Chem chemistry, into the next version of BCC-GEOS-Chem. Diagnosing radiative transfer and aerosol-cloud interactions will be the next priority for model evaluation, and it can take advantage of the GEOS-Chem aerosol microphysics module - the TwO-Moment Aerosol Sectional (TOMAS) module (Kodros and Pierce, 2017) or Advanced Particle Microphysics (APM) module (Yu and Luo, 2009). Updates of emissions (e.g., application of new or regional anthropogenic emission inventories) could be merged to BCC-GEOS-Chem with the future implementa- 
tion of the GEOS-Chem emission module (Harvard-NASA Emissions Component, HEMCO) (Keller et al., 2014). BCCGEOS-Chem is ready to be updated to a higher horizontal and vertical resolution of T106 (about $110 \mathrm{~km}, 46$ layers up to $1.5 \mathrm{hPa}$ ) or T266 (about $45 \mathrm{~km}, 56$ layers up to $0.09 \mathrm{hPa}$ ) with recent the BCC-CSM-MR and BCC-CSM-HR (Wu et al., 2019), which will enable applications on air quality prediction in the future.

Code and data availability. The GEOS-Chem model is maintained at the Harvard Atmospheric Chemistry Modeling group (http://acmg.seas.harvard.edu/geos/, The International GEOS-Chem Community, 2018). The source code of BCC-GEOS-Chem v1.0 can be accessed at a DOI repository https://doi.org/10.5281/zenodo.3475649 (Lu, 2019a), and model outputs for 2012-2014 are available at https://doi.org/10.5281/zenodo.3496777 (Lu, 2019b). All source code and data can also be accessed by contacting the corresponding authors Lin Zhang (zhanglg@pku.edu.cn) and Tongwen Wu (twwu@cma.gov.cn).

Author contributions. LZ, TW, DJJ, and JW led the project. XL, LZ, TW, MSL, FZ, and JZ developed the model source code. XL performed model simulations, analyzed data, and prepared the figures with suggestions from all authors. XL, LZ, TW, and DJJ wrote the paper. All authors contributed to the discussion and improvement of the paper.

Competing interests. The authors declare that they have no conflict of interest.

Acknowledgements. This work is supported by the National Key Research and Development Program of China (2017YFC0210102, 2016YFA0602100) and the National Natural Science Foundation of China (41922037). This work is also supported by a grant to the Harvard-China Project on Energy, Economy and Environment from the Harvard Global Institute. Xiao Lu also acknowledges support from the Chinese Scholarship Council.

Financial support. This research has been supported by the National Key Research and Development Program of China (grant nos. 2017YFC0210102, 2016YFA0602100) and the National Natural Science Foundation of China (grant no. 41922037).

Review statement. This paper was edited by Gerd A. Folberth and reviewed by two anonymous referees.

\section{References}

Amos, H. M., Jacob, D. J., Holmes, C. D., Fisher, J. A., Wang, Q., Yantosca, R. M., Corbitt, E. S., Galarneau, E., Rutter, A. P., Gustin, M. S., Steffen, A., Schauer, J. J., Graydon, J. A., Louis, V. L. St., Talbot, R. W., Edgerton, E. S., Zhang, Y., and Sunderland, E. M.: Gas-particle partitioning of atmospheric $\mathrm{Hg}$ (II) and its effect on global mercury deposition, Atmos. Chem. Phys., 12, 591-603, https://doi.org/10.5194/acp-12-591-2012, 2012.

Bey, I., Jacob, D. J., Yantosca, R. M., Logan, J. A., Field, B. D., Fiore, A. M., Li, Q., Liu, H. Y., Mickley, L. J., and Schultz, M. G.: Global modeling of tropospheric chemistry with assimilated meteorology: Model description and evaluation, J. Geophys. Res., 106, 23073-23095, https://doi.org/10.1029/2001jd000807, 2001.

Bian, H. and Prather, M. J.: Fast-J2: Accurate Simulation of Stratospheric Photolysis in Global Chemical Models, J. Atmos. Chem. 41, 281-296, https://doi.org/10.1023/a:1014980619462, 2002.

Collins, W. D., Rasch, P. J., Boville, B. A., Hack, J. J., McCaa, J. R., Williamson, D. L., Briegleb, B. P., Bitz, C. M., Lin, S.-J., and Zhang, M.: The Formulation and Atmospheric Simulation of the Community Atmosphere Model Version 3 (CAM3), J. Climate, 19, 2144-2161, https://doi.org/10.1175/jcli3760.1, 2006.

Cooper, O. R., Schultz, M. G., Schroeder, S., Chang, K.-L., Gaudel, A., Benítez, G. C., Cuevas, E., Fröhlich, M., Galbally, I. E., Molloy, S., Kubistin, D., Lu, X., McClure-Begley, A., Nédélec, P., O’Brien, J., Oltmans, S. J., Petropavlovskikh, I., Ries, L., Senik, I., Sjöberg, K., Solberg, S., Spain, G. T., Spangl, W., Steinbacher, M., Tarasick, D., Thouret, V., and Xu, X.: Multi-decadal surface ozone trends at globally distributed remote locations, Elem. Sci. Anth., 8, 23, https://doi.org/10.1525/elementa.420, 2020.

Council, N. R.: A National Strategy for Advancing Climate Modeling, The National Academies Press, Washington DC, USA, https://doi.org/10.17226/13430, 2012.

Deeter, M. N., Edwards, D. P., Francis, G. L., Gille, J. C., Martínez-Alonso, S., Worden, H. M., and Sweeney, C.: A climate-scale satellite record for carbon monoxide: the MOPITT Version 7 product, Atmos. Meas. Tech., 10, 2533-2555, https://doi.org/10.5194/amt-10-2533-2017, 2017.

De Smedt, I., Stavrakou, T., Hendrick, F., Danckaert, T., Vlemmix, T., Pinardi, G., Theys, N., Lerot, C., Gielen, C., Vigouroux, C., Hermans, C., Fayt, C., Veefkind, P., Müller, J.-F., and Van Roozendael, M.: Diurnal, seasonal and long-term variations of global formaldehyde columns inferred from combined OMI and GOME-2 observations, Atmos. Chem. Phys., 15, 12519-12545, https://doi.org/10.5194/acp-15-12519-2015, 2015.

Eastham, S. D., Weisenstein, D. K., and Barrett, S. R. H.: Development and evaluation of the unified troposphericstratospheric chemistry extension (UCX) for the global chemistry-transport model GEOS-Chem, Atmos. Environ., 89, 52-63, https://doi.org/10.1016/j.atmosenv.2014.02.001, 2014.

Eastham, S. D., Long, M. S., Keller, C. A., Lundgren, E., Yantosca, R. M., Zhuang, J., Li, C., Lee, C. J., Yannetti, M., Auer, B. M., Clune, T. L., Kouatchou, J., Putman, W. M., Thompson, M. A., Trayanov, A. L., Molod, A. M., Martin, R. V., and Jacob, D. J.: GEOS-Chem High Performance (GCHP v11-02c): a next-generation implementation of the GEOS-Chem chemical transport model for massively parallel applications, Geosci. Model Dev., 11, 2941-2953, https://doi.org/10.5194/gmd-112941-2018, 2018. 
Emmons, L. K., Deeter, M. N., Gille, J. C., Edwards, D. P., Attié, J. L., Warner, J., Ziskin, D., Francis, G., Khattatov, B., Yudin, V., Lamarque, J. F., Ho, S. P., Mao, D., Chen, J. S., Drummond, J., Novelli, P., Sachse, G., Coffey, M. T., Hannigan, J. W., Gerbig, C., Kawakami, S., Kondo, Y., Takegawa, N., Schlager, H., Baehr, J., and Ziereis, H.: Validation of Measurements of Pollution in the Troposphere (MOPITT) CO retrievals with aircraft in situ profiles, J. Geophys. Res., 109, D03309, https://doi.org/10.1029/2003jd004101, 2004.

Emmons, L. K., Walters, S., Hess, P. G., Lamarque, J.-F., Pfister, G. G., Fillmore, D., Granier, C., Guenther, A., Kinnison, D., Laepple, T., Orlando, J., Tie, X., Tyndall, G., Wiedinmyer, C., Baughcum, S. L., and Kloster, S.: Description and evaluation of the Model for Ozone and Related chemical Tracers, version 4 (MOZART-4), Geosci. Model Dev., 3, 43-67, https://doi.org/10.5194/gmd-3-43-2010, 2010.

Evans, M. J. and Jacob, D.: Impact of new laboratory studies of $\mathrm{N}_{2} \mathrm{O}_{5}$ hydrolysis on global model budgets of tropospheric nitrogen oxides, ozone, and $\mathrm{OH}$, Geophys. Res. Lett., 32, L09813, https://doi.org/10.1029/2005gl022469, 2005.

Eyring, V., Bony, S., Meehl, G. A., Senior, C. A., Stevens, B., Stouffer, R. J., and Taylor, K. E.: Overview of the Coupled Model Intercomparison Project Phase 6 (CMIP6) experimental design and organization, Geosci. Model Dev., 9, 1937-1958, https://doi.org/10.5194/gmd-9-1937-2016, 2016.

Fairlie, T. D., Jacob, D. J., and Park, R. J.: The impact of transpacific transport of mineral dust in the United States, Atmos. Environ., 41, 1251-1266, https://doi.org/10.1016/j.atmosenv.2006.09.048, 2007.

Fiore, A. M., Naik, V., Spracklen, D. V., Steiner, A., Unger, N., Prather, M., Bergmann, D., Cameron-Smith, P. J., Cionni, I., Collins, W. J., Dalsoren, S., Eyring, V., Folberth, G. A., Ginoux, P., Horowitz, L. W., Josse, B., Lamarque, J. F., MacKenzie, I. A., Nagashima, T., O'Connor, F. M., Righi, M., Rumbold, S. T., Shindell, D. T., Skeie, R. B., Sudo, K., Szopa, S., Takemura, T., and Zeng, G.: Global air quality and climate, Chem. Soc. Rev., 41, 6663-6683, https://doi.org/10.1039/c2cs35095e, 2012.

Fischer, E. V., Jacob, D. J., Yantosca, R. M., Sulprizio, M. P., Millet, D. B., Mao, J., Paulot, F., Singh, H. B., Roiger, A., Ries, L., Talbot, R. W., Dzepina, K., and Pandey Deolal, S.: Atmospheric peroxyacetyl nitrate (PAN): a global budget and source attribution, Atmos. Chem. Phys., 14, 2679-2698, https://doi.org/10.5194/acp-14-2679-2014, 2014.

Fountoukis, C. and Nenes, A.: ISORROPIA II: a computationally efficient thermodynamic equilibrium model for $\mathrm{K}^{+}-$ $\mathrm{Ca}^{2+}-\mathrm{Mg}^{2+}-\mathrm{NH}_{4}^{+}-\mathrm{Na}^{+}-\mathrm{SO}_{4}^{2-}-\mathrm{NO}_{3}^{-}-\mathrm{Cl}^{-}-\mathrm{H}_{2} \mathrm{O}$ aerosols, Atmos. Chem. Phys., 7, 4639-4659, https://doi.org/10.5194/acp-74639-2007, 2007.

Geddes, J. A., Heald, C. L., Silva, S. J., and Martin, R. V.: Land cover change impacts on atmospheric chemistry: simulating projected large-scale tree mortality in the United States, Atmos. Chem. Phys., 16, 2323-2340, https://doi.org/10.5194/acp-162323-2016, 2016.

Gong, S. L., Barrie, L. A., and Blanchet, J. P.: Modeling sea-salt aerosols in the atmosphere: 1. Model development, J. Geophys. Res., 102, 3805-3818, https://doi.org/10.1029/96jd02953, 1997.

Guenther, A. B., Jiang, X., Heald, C. L., Sakulyanontvittaya, T., Duhl, T., Emmons, L. K., and Wang, X.: The Model of Emissions of Gases and Aerosols from Nature version 2.1
(MEGAN2.1): an extended and updated framework for modeling biogenic emissions, Geosci. Model Dev., 5, 1471-1492, https://doi.org/10.5194/gmd-5-1471-2012, 2012.

Hardacre, C., Wild, O., and Emberson, L.: An evaluation of ozone dry deposition in global scale chemistry climate models, Atmos. Chem. Phys., 15, 6419-6436, https://doi.org/10.5194/acp15-6419-2015, 2015.

Hoesly, R. M., Smith, S. J., Feng, L., Klimont, Z., JanssensMaenhout, G., Pitkanen, T., Seibert, J. J., Vu, L., Andres, R. J., Bolt, R. M., Bond, T. C., Dawidowski, L., Kholod, N., Kurokawa, J.-I., Li, M., Liu, L., Lu, Z., Moura, M. C. P., O'Rourke, P. R., and Zhang, Q.: Historical (1750-2014) anthropogenic emissions of reactive gases and aerosols from the Community Emissions Data System (CEDS), Geosci. Model Dev., 11, 369-408, https://doi.org/10.5194/gmd-11-369-2018, 2018.

Holtslag, A. A. M. and Boville, B. A.: Local versus nonlocal boundary-layer diffusion in a global climate model, J. Climate, 6, 1825-1842, 1993.

Hu, L., Jacob, D. J., Liu, X., Zhang, Y., Zhang, L., Kim, P. S., Sulprizio, M. P., and Yantosca, R. M.: Global budget of tropospheric ozone: Evaluating recent model advances with satellite (OMI), aircraft (IAGOS), and ozonesonde observations, Atmos. Environ., 167, 323-334, https://doi.org/10.1016/j.atmosenv.2017.08.036, 2017.

Hu, L., Keller, C. A., Long, M. S., Sherwen, T., Auer, B., Da Silva, A., Nielsen, J. E., Pawson, S., Thompson, M. A., Trayanov, A. L., Travis, K. R., Grange, S. K., Evans, M. J., and Jacob, D. J.: Global simulation of tropospheric chemistry at 12.5 $\mathrm{km}$ resolution: performance and evaluation of the GEOS-Chem chemical module (v10-1) within the NASA GEOS Earth system model (GEOS-5 ESM), Geosci. Model Dev., 11, 4603-4620, https://doi.org/10.5194/gmd-11-4603-2018, 2018.

Huang, G., Liu, X., Chance, K., Yang, K., Bhartia, P. K., Cai, Z., Allaart, M., Ancellet, G., Calpini, B., Coetzee, G. J. R., CuevasAgulló, E., Cupeiro, M., De Backer, H., Dubey, M. K., Fuelberg, H. E., Fujiwara, M., Godin-Beekmann, S., Hall, T. J., Johnson, B., Joseph, E., Kivi, R., Kois, B., Komala, N., König-Langlo, G., Laneve, G., Leblanc, T., Marchand, M., Minschwaner, K. R., Morris, G., Newchurch, M. J., Ogino, S.-Y., Ohkawara, N., Piters, A. J. M., Posny, F., Querel, R., Scheele, R., Schmidlin, F. J., Schnell, R. C., Schrems, O., Selkirk, H., Shiotani, M., Skrivánková, P., Stübi, R., Taha, G., Tarasick, D. W., Thompson, A. M., Thouret, V., Tully, M. B., Van Malderen, R., Vömel, H., von der Gathen, P., Witte, J. C., and Yela, M.: Validation of 10-year SAO OMI Ozone Profile (PROFOZ) product using ozonesonde observations, Atmos. Meas. Tech., 10, 2455-2475, https://doi.org/10.5194/amt-10-2455-2017, 2017.

Huang, G., Liu, X., Chance, K., Yang, K., and Cai, Z.: Validation of 10-year SAO OMI ozone profile (PROFOZ) product using Aura MLS measurements, Atmos. Meas. Tech., 11, 17-32, https://doi.org/10.5194/amt-11-17-2018, 2018.

IPCC: Climate Change 2013: The Physical Science Basis. Contribution of Working Group I to the Fifth Assessment Report of the Intergovernmental Panel on Climate Change, edited by: Stocker, T. F., Qin, D., Plattner, G.-K., Tignor, M., Allen, S. K., Boschung, J., Nauels, A., Xia, Y., Bex, V., and Midgley, P. M., Cambridge University Press, Cambridge, United Kingdom and New York, NY, USA, 1535 pp., https://doi.org/10.1017/CBO9781107415324, 2013. 
Jacob, D.: Heterogeneous chemistry and tropospheric ozone, Atmos. Environ., 34, 2131-2159, https://doi.org/10.1016/s13522310(99)00462-8, 2000.

Jacob, D. J. and Winner, D. A.: Effect of climate change on air quality, Atmos. Environ., 43, 51-63, https://doi.org/10.1016/j.atmosenv.2008.09.051, 2009.

Jaeglé, L., Quinn, P. K., Bates, T. S., Alexander, B., and Lin, J.-T.: Global distribution of sea salt aerosols: new constraints from in situ and remote sensing observations, Atmos. Chem. Phys., 11, 3137-3157, https://doi.org/10.5194/acp-11-3137-2011, 2011.

Ji, J.: A Climate-Vegetation Interaction Model: Simulating Physical and Biological Processes at the Surface, J. Biogeogr., 22, 445451, https://doi.org/10.2307/2845941, 1995.

Ji, J., Huang, M., and Li, K.: Prediction of carbon exchanges between China terrestrial ecosystem and atmosphere in 21st century, Sci. China Ser. D, 51, 885-898, https://doi.org/10.1007/s11430-008-0039-y, 2008.

Keller, C. A., Long, M. S., Yantosca, R. M., Da Silva, A. M., Pawson, S., and Jacob, D. J.: HEMCO v1.0: a versatile, ESMF-compliant component for calculating emissions in atmospheric models, Geosci. Model Dev., 7, 1409-1417, https://doi.org/10.5194/gmd-7-1409-2014, 2014.

Kodros, J. K. and Pierce, J. R.: Important global and regional differences in cloud-albedo aerosol indirect effect estimates between simulations with and without prognostic aerosol microphysics, J. Geophys. Res., 122, 4003-4018, https://doi.org/10.1002/2016JD025886, 2017.

Krotkov, N. A., Li. C., and Leonard, P.: OMI/Aura Sulfur Dioxide (SO2) Total Column L3 1 day Best Pixel in 0.25 degree x 0.25 degree V3, Greenbelt, MD, USA, Goddard Earth Sciences Data and Information Services Center (GES DISC), https://doi.org/10.5067/Aura/OMI/DATA3008, 2015.

Krotkov, N. A., Lamsal, L. N., Marchenko, S. V., Celarier, E. A., Bucsela, E. J., Swartz, W. H., Joiner, J., and the OMI core team: OMI/Aura $\mathrm{NO}_{2}$ Cloud-Screened Total and Tropospheric Column L3 Global Gridded 0.25 degree $\times 0.25$ degree V3, NASA Goddard Space Flight Center, Goddard Earth Sciences Data and Information Services Center (GES DISC), https://doi.org/10.5067/Aura/OMI/DATA3007, 2019.

Lamarque, J.-F., Bond, T. C., Eyring, V., Granier, C., Heil, A., Klimont, Z., Lee, D., Liousse, C., Mieville, A., Owen, B., Schultz, M. G., Shindell, D., Smith, S. J., Stehfest, E., Van Aardenne, J., Cooper, O. R., Kainuma, M., Mahowald, N., McConnell, J. R., Naik, V., Riahi, K., and van Vuuren, D. P.: Historical (1850-2000) gridded anthropogenic and biomass burning emissions of reactive gases and aerosols: methodology and application, Atmos. Chem. Phys., 10, 7017-7039, https://doi.org/10.5194/acp-10-7017-2010, 2010.

Lamarque, J.-F., Emmons, L. K., Hess, P. G., Kinnison, D. E., Tilmes, S., Vitt, F., Heald, C. L., Holland, E. A., Lauritzen, P. H., Neu, J., Orlando, J. J., Rasch, P. J., and Tyndall, G. K.: CAM-chem: description and evaluation of interactive atmospheric chemistry in the Community Earth System Model, Geosci. Model Dev., 5, 369-411, https://doi.org/10.5194/gmd-5369-2012, 2012.

Lee, C., Martin, R. V., van Donkelaar, A., O’Byrne, G., Krotkov, N., Richter, A., Huey, L. G., and Holloway, J. S.: Retrieval of vertical columns of sulfur dioxide from SCIAMACHY and OMI: Air mass factor algorithm development, valida- tion, and error analysis, J. Geophys. Res., 114, D22303, https://doi.org/10.1029/2009jd012123, 2009.

Li, W., Zhang, Y., Shi, X., Zhou, W., Huang, A., Mu, M., and Ji, J.: Development of Land Surface Model BCC_AVIM2.0 and its Preliminary Performances in LS3MIP/CMIP6, J. Meteorol. Res., 33, 851-869, https://doi.org/10.1007/s13351-019-9016-y, 2019.

Lin, H., Feng, X., Fu, T.-M., Tian, H., Ma, Y., Zhang, L., Jacob, D. J., Yantosca, R. M., Sulprizio, M. P., Lundgren, E. W., Zhuang, J., Zhang, Q., Lu, X., Zhang, L., Shen, L., Guo, J., Eastham, S. D., and Keller, C. A.: WRF-GC (v1.0): online coupling of WRF (v3.9.1.1) and GEOS-Chem (v12.2.1) for regional atmospheric chemistry modeling - Part 1: Description of the one-way model, Geosci. Model Dev., 13, 3241-3265, https://doi.org/10.5194/gmd-13-3241-2020, 2020.

Liu, H., Jacob, D. J., Bey, I., and Yantosca, R. M.: Constraints from $210 \mathrm{~Pb}$ and $7 \mathrm{Be}$ on wet deposition and transport in a global three-dimensional chemical tracer model driven by assimilated meteorological fields, J. Geophys. Res., 106, 12109-12128, https://doi.org/10.1029/2000jd900839, 2001.

Liu, X., Chance, K., Sioris, C. E., Spurr, R. J. D., Kurosu, T. P., Martin, R. V., and Newchurch, M. J.: Ozone profile and tropospheric ozone retrievals from the Global Ozone Monitoring Experiment: Algorithm description and validation, J. Geophys. Res., 110, D20307, https://doi.org/10.1029/2005jd006240, 2005.

Liu, X., Bhartia, P. K., Chance, K., Spurr, R. J. D., and Kurosu, T. P.: Ozone profile retrievals from the Ozone Monitoring Instrument, Atmos. Chem. Phys., 10, 2521-2537, https://doi.org/10.5194/acp-10-2521-2010, 2010.

Long, M. S., Yantosca, R., Nielsen, J. E., Keller, C. A., da Silva, A., Sulprizio, M. P., Pawson, S., and Jacob, D. J.: Development of a grid-independent GEOS-Chem chemical transport model (v9-02) as an atmospheric chemistry module for Earth system models, Geosci. Model Dev., 8, 595-602, https://doi.org/10.5194/gmd-8-595-2015, 2015.

Lu, X.: BCC-GEOS-Chem v1.0 source code (atmosphere only), Zenodo, https://doi.org/10.5281/zenodo.3475649, 2019a.

Lu, X.: BCC-GEOS-Chem v1.0 model output (2012-2014) [Data set], Zenodo, https://doi.org/10.5281/zenodo.3496777, 2019 b.

Lu, X., Zhang, L., Liu, X., Gao, M., Zhao, Y., and Shao, J.: Lower tropospheric ozone over India and its linkage to the South Asian monsoon, Atmos. Chem. Phys., 18, 3101-3118, https://doi.org/10.5194/acp-18-3101-2018, 2018.

Lu, X., Zhang, L., and Shen, L.: Meteorology and Climate Influences on Tropospheric Ozone: a Review of Natural Sources, Chemistry, and Transport Patterns, Current Pollution Reports, 5, 238-260, https://doi.org/10.1007/s40726-019-00118-3, 2019a.

Lu, X., Zhang, L., Zhao, Y., Jacob, D. J., Hu, Y., Hu, L., Gao, M., Liu, X., Petropavlovskikh, I., McClure-Begley, A., and Querel, R.: Surface and tropospheric ozone trends in the Southern Hemisphere since 1990: possible linkages to poleward expansion of the Hadley circulation, Sci. Bull., 64, 400-409, https://doi.org/10.1016/j.scib.2018.12.021, 2019b.

Mao, J., Jacob, D. J., Evans, M. J., Olson, J. R., Ren, X., Brune, W. H., Clair, J. M. St., Crounse, J. D., Spencer, K. M., Beaver, M. R., Wennberg, P. O., Cubison, M. J., Jimenez, J. L., Fried, A., Weibring, P., Walega, J. G., Hall, S. R., Weinheimer, A. J., Cohen, R. C., Chen, G., Crawford, J. H., McNaughton, C., Clarke, A. D., Jaeglé, L., Fisher, J. A., Yantosca, R. M., Le Sager, P., and Carouge, C.: Chemistry of hydrogen oxide radicals (HOx) in 
the Arctic troposphere in spring, Atmos. Chem. Phys., 10, 58235838, https://doi.org/10.5194/acp-10-5823-2010, 2010.

Mao, J., Paulot, F., Jacob, D. J., Cohen, R. C., Crounse, J. D., Wennberg, P. O., Keller, C. A., Hudman, R. C., Barkley, M. P., and Horowitz, L. W.: Ozone and organic nitrates over the eastern United States: Sensitivity to isoprene chemistry, J. Geophys. Res., 118, 11256-211268, https://doi.org/10.1002/jgrd.50817, 2013.

Marais, E. A., Jacob, D. J., Jimenez, J. L., Campuzano-Jost, P., Day, D. A., Hu, W., Krechmer, J., Zhu, L., Kim, P. S., Miller, C. C., Fisher, J. A., Travis, K., Yu, K., Hanisco, T. F., Wolfe, G. M., Arkinson, H. L., Pye, H. O. T., Froyd, K. D., Liao, J., and McNeill, V. F.: Aqueous-phase mechanism for secondary organic aerosol formation from isoprene: application to the southeast United States and co-benefit of $\mathrm{SO}_{2}$ emission controls, Atmos. Chem. Phys., 16, 1603-1618, https://doi.org/10.5194/acp16-1603-2016, 2016.

Martin, R. V., Jacob, D. J., Yantosca, R. M., Chin, M., and Ginoux, P.: Global and regional decreases in tropospheric oxidants from photochemical effects of aerosols, J. Geophys. Res., 108, 4097, https://doi.org/10.1029/2002jd002622, 2003.

McLinden, C. A., Olsen, S. C., Hannegan, B., Wild, O., Prather, M. J., and Sundet, J.: Stratospheric ozone in 3-D models: A simple chemistry and the cross-tropopause flux, J. Geophys. Res., 105, 14653-14665, https://doi.org/10.1029/2000jd900124, 2000.

Meinshausen, M., Vogel, E., Nauels, A., Lorbacher, K., Meinshausen, N., Etheridge, D. M., Fraser, P. J., Montzka, S. A., Rayner, P. J., Trudinger, C. M., Krummel, P. B., Beyerle, U., Canadell, J. G., Daniel, J. S., Enting, I. G., Law, R. M., Lunder, C. R., O’Doherty, S., Prinn, R. G., Reimann, S., Rubino, M., Velders, G. J. M., Vollmer, M. K., Wang, R. H. J., and Weiss, R.: Historical greenhouse gas concentrations for climate modelling (CMIP6), Geosci. Model Dev., 10, 2057-2116, https://doi.org/10.5194/gmd-10-2057-2017, 2017.

Millet, D. B., Guenther, A., Siegel, D. A., Nelson, N. B., Singh, H. B., de Gouw, J. A., Warneke, C., Williams, J., Eerdekens, G., Sinha, V., Karl, T., Flocke, F., Apel, E., Riemer, D. D., Palmer, P. I., and Barkley, M.: Global atmospheric budget of acetaldehyde: 3-D model analysis and constraints from in-situ and satellite observations, Atmos. Chem. Phys., 10, 3405-3425, https://doi.org/10.5194/acp-10-3405-2010, 2010.

Monahan, E. C., Spiel, D. E., and Davidso, K. L.: A Model of Marine Aerosol Generation Via Whitecaps and Wave Disruption, Springer Netherlands, Dordrecht, 167-174, https://doi.org/10.1007/978-94-009-4668-2_16, 1986.

Naik, V., Voulgarakis, A., Fiore, A. M., Horowitz, L. W., Lamarque, J.-F., Lin, M., Prather, M. J., Young, P. J., Bergmann, D., Cameron-Smith, P. J., Cionni, I., Collins, W. J., Dalsøren, S. B., Doherty, R., Eyring, V., Faluvegi, G., Folberth, G. A., Josse, B., Lee, Y. H., MacKenzie, I. A., Nagashima, T., van Noije, T. P. C., Plummer, D. A., Righi, M., Rumbold, S. T., Skeie, R., Shindell, D. T., Stevenson, D. S., Strode, S., Sudo, K., Szopa, S., and Zeng, G.: Preindustrial to present-day changes in tropospheric hydroxyl radical and methane lifetime from the Atmospheric Chemistry and Climate Model Intercomparison Project (ACCMIP), Atmos. Chem. Phys., 13, 5277-5298, https://doi.org/10.5194/acp13-5277-2013, 2013.

Nicely, J. M., Duncan, B. N., Hanisco, T. F., Wolfe, G. M., Salawitch, R. J., Deushi, M., Haslerud, A. S., Jöckel, P., Josse, B.,
Kinnison, D. E., Klekociuk, A., Manyin, M. E., Marécal, V., Morgenstern, O., Murray, L. T., Myhre, G., Oman, L. D., Pitari, G., Pozzer, A., Quaglia, I., Revell, L. E., Rozanov, E., Stenke, A., Stone, K., Strahan, S., Tilmes, S., Tost, H., Westervelt, D. M., and Zeng, G.: A machine learning examination of hydroxyl radical differences among model simulations for CCMI-1, Atmos. Chem. Phys., 20, 1341-1361, https://doi.org/10.5194/acp20-1341-2020, 2020.

Ott, L. E., Pickering, K. E., Stenchikov, G. L., Allen, D. J., DeCaria, A. J., Ridley, B., Lin, R.-F., Lang, S., and Tao, W.-K.: Production of lightning NOx and its vertical distribution calculated from three-dimensional cloud-scale chemical transport model simulations, J. Geophys. Res., 115, D04301, https://doi.org/10.1029/2009jd011880, 2010.

Park, R. J., Jacob, D. J., Field, B. D., Yantosca, R. M., and Chin, M.: Natural and transboundary pollution influences on sulfate-nitrate-ammonium aerosols in the United States: Implications for policy, J. Geophys. Res.-Atmos., 109, D15204, https://doi.org/10.1029/2003jd004473, 2004.

Parrella, J. P., Jacob, D. J., Liang, Q., Zhang, Y., Mickley, L. J., Miller, B., Evans, M. J., Yang, X., Pyle, J. A., Theys, N., and Van Roozendael, M.: Tropospheric bromine chemistry: implications for present and pre-industrial ozone and mercury, Atmos. Chem. Phys., 12, 6723-6740, https://doi.org/10.5194/acp12-6723-2012, 2012.

Pfister, G., Hess, P. G., Emmons, L. K., Lamarque, J. F., Wiedinmyer, C., Edwards, D. P., Petron, G., Gille, J. C., and Sachse, G. W.: Quantifying CO emissions from the 2004 Alaskan wildfires using MOPITT CO data, Geophys. Res. Lett., 32, L11809, https://doi.org/10.1029/2005gl022995, 2005.

Price, C. and Rind, D.: A simple lightning parameterization for calculating global lightning distributions, J. Geophys. Res., 97, 9919-9933, https://doi.org/10.1029/92jd00719, 1992.

Price, C., Penner, J., and Prather, M.: NOx from lightning: 1. Global distribution based on lightning physics, J. Geophys. Res., 102, 5929-5941, https://doi.org/10.1029/96jd03504, 1997.

Pye, H. O. T., Liao, H., Wu, S., Mickley, L. J., Jacob, D. J., Henze, D. K., and Seinfeld, J. H.: Effect of changes in climate and emissions on future sulfate-nitrate-ammonium aerosol levels in the United States, J. Geophys. Res., 114, D01205, https://doi.org/10.1029/2008jd010701, 2009.

Rodgers, C. D.: Inverse Methods for Atmospheric Sounding: Theory and Practice, World Scientific, Singapore, 2000.

Sauvage, B., Martin, R. V., van Donkelaar, A., and Ziemke, J. R.: Quantification of the factors controlling tropical tropospheric ozone and the South Atlantic maximum, J. Geophys. Res., 112, D11309, https://doi.org/10.1029/2006JD008008, 2007.

Schultz, M. G., Schröder, S., Lyapina, O., Cooper, O., Galbally, I., Petropavlovskikh, I., Von Schneidemesser, E., Tanimoto, H., Elshorbany, Y., Naja, M., Seguel, R., Dauert, U., Eckhardt, P., Feigenspahn, S., Fiebig, M., Hjellbrekke, A.-G., Hong, Y.-D., Christian Kjeld, P., Koide, H., Lear, G., Tarasick, D., Ueno, M., Wallasch, M., Baumgardner, D., Chuang, M.-T., Gillett, R., Lee, M., Molloy, S., Moolla, R., Wang, T., Sharps, K., Adame, J. A., Ancellet, G., Apadula, F., Artaxo, P., Barlasina, M., Bogucka, M., Bonasoni, P., Chang, L., Colomb, A., Cuevas, E., Cupeiro, M., Degorska, A., Ding, A., Fröhlich, M., Frolova, M., Gadhavi, H., Gheusi, F., Gilge, S., Gonzalez, M. Y., Gros, V., Hamad, S. H., Helmig, D., Henriques, D., Hermansen, O., Holla, R., Hu- 
ber, J., Im, U., Jaffe, D. A., Komala, N., Kubistin, D., Lam, K.-S., Laurila, T., Lee, H., Levy, I., Mazzoleni, C., Mazzoleni, L., McClure-Begley, A., Mohamad, M., Murovic, M., NavarroComas, M., Nicodim, F., Parrish, D., Read, K. A., Reid, N., Ries, L., Saxena, P., Schwab, J. J., Scorgie, Y., Senik, I., Simmonds, P., Sinha, V., Skorokhod, A., Spain, G., Spangl, W., Spoor, R., Springston, S. R., Steer, K., Steinbacher, M., Suharguniyawan, E., Torre, P., Trickl, T., Weili, L., Weller, R., Xu, X., Xue, L., and Zhiqiang, M.: Tropospheric Ozone Assessment Report, links to Global surface ozone datasets, PANGAEA, https://doi.org/10.1594/PANGAEA.876108, 2017a.

Schultz, M. G., Schröder, S., Lyapina, O., Cooper, O., Galbally, I., Petropavlovskikh, I., Von Schneidemesser, E., Tanimoto, H., Elshorbany, Y., Naja, M., Seguel, R., Dauert, U., Eckhardt, P., Feigenspahn, S., Fiebig, M., Hjellbrekke, A.-G., Hong, Y.-D., Christian Kjeld, P., Koide, H., Lear, G., Tarasick, D., Ueno, M., Wallasch, M., Baumgardner, D., Chuang, M.-T., Gillett, R., Lee, M., Molloy, S., Moolla, R., Wang, T., Sharps, K., Adame, J. A., Ancellet, G., Apadula, F., Artaxo, P., Barlasina, M., Bogucka, M., Bonasoni, P., Chang, L., Colomb, A., Cuevas, E., Cupeiro, M., Degorska, A., Ding, A., Fröhlich, M., Frolova, M., Gadhavi, H., Gheusi, F., Gilge, S., Gonzalez, M. Y., Gros, V., Hamad, S. H., Helmig, D., Henriques, D., Hermansen, O., Holla, R., Huber, J., Im, U., Jaffe, D. A., Komala, N., Kubistin, D., Lam, K.-S., Laurila, T., Lee, H., Levy, I., Mazzoleni, C., Mazzoleni, L., McClure-Begley, A., Mohamad, M., Murovic, M., NavarroComas, M., Nicodim, F., Parrish, D., Read, K. A., Reid, N., Ries, L., Saxena, P., Schwab, J. J., Scorgie, Y., Senik, I., Simmonds, P., Sinha, V., Skorokhod, A., Spain, G., Spangl, W., Spoor, R., Springston, S. R., Steer, K., Steinbacher, M., Suharguniyawan, E., Torre, P., Trickl, T., Weili, L., Weller, R., Xu, X., Xue, L., and Zhiqiang, M.: Tropospheric Ozone Assessment Report: Database and Metrics Data of Global Surface Ozone Observations, Elem. Sci. Anth., 5, 53, https://doi.org/10.1525/elementa.244, $2017 \mathrm{~b}$.

Schumann, U. and Huntrieser, H.: The global lightning-induced nitrogen oxides source, Atmos. Chem. Phys., 7, 3823-3907, https://doi.org/10.5194/acp-7-3823-2007, 2007.

Spivakovsky, C. M., Logan, J. A., Montzka, S. A., Balkanski, Y. J., Foreman-Fowler, M., Jones, D. B. A., Horowitz, L. W., Fusco, A. C., Brenninkmeijer, C. A. M., Prather, M. J., Wofsy, S. C., and McElroy, M. B.: Three-dimensional climatological distribution of tropospheric OH: Update and evaluation, J. Geophys. Res., 105, 8931-8980, https://doi.org/10.1029/1999jd901006, 2000.

Stevens, B., Fiedler, S., Kinne, S., Peters, K., Rast, S., Müsse, J., Smith, S. J., and Mauritsen, T.: MACv2-SP: a parameterization of anthropogenic aerosol optical properties and an associated Twomey effect for use in CMIP6, Geosci. Model Dev., 10, 433452, https://doi.org/10.5194/gmd-10-433-2017, 2017.

Thompson, A. M., Witte, J. C., McPeters, R. D., Oltmans, S. J., Schmidlin, F. J., Logan, J. A., Fujiwara, M., Kirchhoff, V. W., Posny, F., Coetzee, G. J., Hoegger, B., Kawakami, S., Ogawa, T., Johnson, B. J., Vömel, H., and Labow, G.: Southern Hemisphere Additional 35 Ozonesondes (SHADOZ) 1998-2000 tropical ozone climatology 1. Comparison with Total Ozone Mapping Spectrometer (TOMS) and ground-based measurements, J. Geophys. Res., 108, 8238, https://doi.org/10.1029/2001jd000967, 2003.

Tilmes, S., Lamarque, J.-F., Emmons, L. K., Conley, A., Schultz, M. G., Saunois, M., Thouret, V., Thompson, A. M., Olt- mans, S. J., Johnson, B., and Tarasick, D.: Technical Note: Ozonesonde climatology between 1995 and 2011: description, evaluation and applications, Atmos. Chem. Phys., 12, 74757497, https://doi.org/10.5194/acp-12-7475-2012, 2012.

van Marle, M. J. E., Kloster, S., Magi, B. I., Marlon, J. R., Daniau, A.-L., Field, R. D., Arneth, A., Forrest, M., Hantson, S., Kehrwald, N. M., Knorr, W., Lasslop, G., Li, F., Mangeon, S., Yue, C., Kaiser, J. W., and van der Werf, G. R.: Historic global biomass burning emissions for CMIP6 (BB4CMIP) based on merging satellite observations with proxies and fire models (1750-2015), Geosci. Model Dev., 10, 3329-3357, https://doi.org/10.5194/gmd-10-3329-2017, 2017.

Wang, S., Hornbrook, R. S., Hills, A., Emmons, L. K., Tilmes, S., Lamarque, J. F., Jimenez, J. L., Campuzano-Jost, P., Nault, B. A., Crounse, J. D., Wennberg, P. O., Kim, M., Allen, H., Ryerson, T. B., Thompson, C. R., Peischl, J., Moore, F., Nance, D., Hall, B., Elkins, J., Tanner, D., Huey, L. G., Hall, S. R., Ullmann, K., Orlando, J. J., Tyndall, G. S., Flocke, F. M., Ray, E., Hanisco, T. F., Wolfe, G. M., St. Clair, J., Commane, R., Daube, B., Barletta, B., Blake, D. R., Weinzierl, B., Dollner, M., Conley, A., Vitt, F., Wofsy, S. C., Riemer, D. D., and Apel, E. C.: Atmospheric Acetaldehyde: Importance of Air-Sea Exchange and a Missing Source in the Remote Troposphere, Geophys. Res. Lett., 46, 5601-5613, https://doi.org/10.1029/2019g1082034, 2019.

Wesely, M. L.: Parameterization of Surface Resistances to Gaseous Dry Deposition in Regional-Scale Numerical-Models, Atmos. Environ., 23, 1293-1304, https://doi.org/10.1016/00046981(89)90153-4, 1989.

Williamson, D. L. and Rasch, P. J.: Two-dimensional semiLagrangian transport with shapepreserving interpolation, Mon. Weather Rev., 117, 102-129, 1989.

Wu, T., Yu, R., and Zhang, F.: A Modified Dynamic Framework for the Atmospheric Spectral Model and Its Application, J. Atmos. Sci., 65, 2235-2253, https://doi.org/10.1175/2007jas2514.1, 2008.

Wu, T.: A mass-flux cumulus parameterization scheme for largescale models: description and test with observations, Clim. Dynam., 38, 725-744, https://doi.org/10.1007/s00382-011-0995-3, 2012.

Wu, T., Yu, R., Zhang, F., Wang, Z., Dong, M., Wang, L., Jin, X., Chen, D., and Li, L.: The Beijing Climate Center atmospheric general circulation model: description and its performance for the present-day climate, Clim. Dynam., 34, 123-147, https://doi.org/10.1007/s00382-008-0487-2, 2010.

Wu, T., Li, W., Ji, J., Xin, X., Li, L., Wang, Z., Zhang, Y., Li, J., Zhang, F., Wei, M., Shi, X., Wu, F., Zhang, L., Chu, M., Jie, W., Liu, Y., Wang, F., Liu, X., Li, Q., Dong, M., Liang, X., Gao, Y., and Zhang, J.: Global carbon budgets simulated by the Beijing Climate Center Climate System Model for the last century, J. Geophys. Res., 118, 4326-4347, https://doi.org/10.1002/jgrd.50320, 2013.

Wu, T., Song, L., Li, W., Wang, Z., Zhang, H., Xin, X., Zhang, Y., Zhang, L., Li, J., Wu, F., Liu, Y., Zhang, F., Shi, X., Chu, M., Zhang, J., Fang, Y., Wang, F., Lu, Y., Liu, X., Wei, M., Liu, Q. Zhou, W., Dong, M., Zhao, Q., Ji, J., Li, L., and Zhou, M.: An overview of BCC climate system model development and application for climate change studies, Acta Meteorol. Sin., 28, 3456, https://doi.org/10.1007/s13351-014-3041-7, 2014. 
Wu, T., Lu, Y., Fang, Y., Xin, X., Li, L., Li, W., Jie, W., Zhang, J., Liu, Y., Zhang, L., Zhang, F., Zhang, Y., Wu, F., Li, J., Chu, M., Wang, Z., Shi, X., Liu, X., Wei, M., Huang, A., Zhang, Y., and Liu, X.: The Beijing Climate Center Climate System Model (BCC-CSM): the main progress from CMIP5 to CMIP6, Geosci. Model Dev., 12, 1573-1600, https://doi.org/10.5194/gmd-121573-2019, 2019.

Wu, T., Zhang, F., Zhang, J., Jie, W., Zhang, Y., Wu, F., Li, L., Yan, J., Liu, X., Lu, X., Tan, H., Zhang, L., Wang, J., and Hu, A.: Beijing Climate Center Earth System Model version 1 (BCCESM1): model description and evaluation of aerosol simulations, Geosci. Model Dev., 13, 977-1005, https://doi.org/10.5194/gmd13-977-2020, 2020.

Xin, X., Wu, T., and Zhang, J.: Introduction of CMIP5 experiments carried out with the climate system models of Beijing Climate Center, Adv. Clim. Change Res., 4, 41-49, https://doi.org/10.3724/SP.J.1248.2013.041, 2013.

Young, P. J., Archibald, A. T., Bowman, K. W., Lamarque, J.-F., Naik, V., Stevenson, D. S., Tilmes, S., Voulgarakis, A., Wild, O., Bergmann, D., Cameron-Smith, P., Cionni, I., Collins, W. J., Dalsøren, S. B., Doherty, R. M., Eyring, V., Faluvegi, G., Horowitz, L. W., Josse, B., Lee, Y. H., MacKenzie, I. A., Nagashima, T., Plummer, D. A., Righi, M., Rumbold, S. T., Skeie, R. B., Shindell, D. T., Strode, S. A., Sudo, K., Szopa, S., and Zeng, G.: Preindustrial to end 21st century projections of tropospheric ozone from the Atmospheric Chemistry and Climate Model Intercomparison Project (ACCMIP), Atmos. Chem. Phys., 13, 20632090, https://doi.org/10.5194/acp-13-2063-2013, 2013.

Young, P. J., Naik, V., Fiore, A. M., Gaudel, A., Guo, J., Lin, M. Y., Neu, J. L., Parrish, D. D., Rieder, H. E., Schnell, J. L., Tilmes, S., Wild, O., Zhang, L., Ziemke, J. R., Brandt, J., Delcloo, A., Doherty, R. M., Geels, C., Hegglin, M. I., Hu, L., Im, U., Kumar, R., Luhar, A., Murray, L., Plummer, D., Rodriguez, J., Saiz-Lopez, A., Schultz, M. G., Woodhouse, M. T., and Zeng, G.: Tropospheric Ozone Assessment Report: Assessment of global-scale model performance for global and regional ozone distributions, variability, and trends, Elem. Sci. Anth., 6, 10, https://doi.org/10.1525/elementa.265, 2018.

Yu, F. and Luo, G.: Simulation of particle size distribution with a global aerosol model: contribution of nucleation to aerosol and CCN number concentrations, Atmos. Chem. Phys., 9, 76917710, https://doi.org/10.5194/acp-9-7691-2009, 2009.

Zender, C. S., Bian, H. S., and Newman, D.: Mineral Dust Entrainment and Deposition (DEAD) model: Description and 1990s dust climatology, J. Geophys. Res., 108, 4416, https://doi.org/10.1029/2002jd002775, 2003

Zhang, L., Jacob, D. J., Liu, X., Logan, J. A., Chance, K., Eldering, A., and Bojkov, B. R.: Intercomparison methods for satellite measurements of atmospheric composition: application to tropospheric ozone from TES and OMI, Atmos. Chem. Phys., 10, 4725-4739, https://doi.org/10.5194/acp-10-4725-2010, 2010.
Zhang, L., Jacob, D. J., Knipping, E. M., Kumar, N., Munger, J. W., Carouge, C. C., van Donkelaar, A., Wang, Y. X., and Chen, D.: Nitrogen deposition to the United States: distribution, sources, and processes, Atmos. Chem. Phys., 12, 4539-4554, https://doi.org/10.5194/acp-12-4539-2012, 2012.

Zhang, L. M., Gong, S. L., Padro, J., and Barrie, L.: A size-segregated particle dry deposition scheme for an atmospheric aerosol module, Atmos. Environ., 35, 549-560, https://doi.org/10.1016/S1352-2310(00)00326-5, 2001.

Zhang, Y., Cooper, O. R., Gaudel, A., Thompson, A. M., Nédélec, P., Ogino, S.-Y., and West, J. J.: Tropospheric ozone change from 1980 to 2010 dominated by equatorward redistribution of emissions, Nat. Geosci., 9, 875-879, https://doi.org/10.1038/ngeo2827, 2016.

Zhao, S. and He, W.: Evaluation of the performance of the Beijing Climate Centre Climate System Model 1.1(m) to simulate precipitation across China based on long-range correlation characteristics, J. Geophys. Res., 120, 12576-12588, https://doi.org/10.1002/2015jd024059, 2015.

Zhao, Y., Zhang, L., Tai, A. P. K., Chen, Y., and Pan, Y.: Responses of surface ozone air quality to anthropogenic nitrogen deposition in the Northern Hemisphere, Atmos. Chem. Phys., 17, 97819796, https://doi.org/10.5194/acp-17-9781-2017, 2017.

Zhu, L., Jacob, D. J., Kim, P. S., Fisher, J. A., Yu, K., Travis, K. R., Mickley, L. J., Yantosca, R. M., Sulprizio, M. P., De Smedt, I., González Abad, G., Chance, K., Li, C., Ferrare, R., Fried, A., Hair, J. W., Hanisco, T. F., Richter, D., Jo Scarino, A., Walega, J., Weibring, P., and Wolfe, G. M.: Observing atmospheric formaldehyde ( $\mathrm{HCHO})$ from space: validation and intercomparison of six retrievals from four satellites (OMI, GOME2A, GOME2B, OMPS) with SEAC4RS aircraft observations over the southeast US, Atmos. Chem. Phys., 16, 1347713490, https://doi.org/10.5194/acp-16-13477-2016, 2016.

Zhu, L., González Abad, G., Nowlan, C. R., Chan Miller, C., Chance, K., Apel, E. C., DiGangi, J. P., Fried, A., Hanisco, T. F., Hornbrook, R. S., Hu, L., Kaiser, J., Keutsch, F. N., Permar, W., St. Clair, J. M., and Wolfe, G. M.: Validation of satellite formaldehyde (HCHO) retrievals using observations from 12 aircraft campaigns, Atmos. Chem. Phys. Discuss., https://doi.org/10.5194/acp-2019-1117, in review, 2020.

Zhuang, J., Jacob, D. J., Gaya, J. F., Yantosca, R. M., Lundgren, E. W., Sulprizio, M. P., and Eastham, S. D.: Enabling immediate access to Earth science models through cloud computing: application to the GEOS-Chem model, B. Am. Meteorol. Soc., 100, 1943-1960, https://doi.org/10.1175/bams-d-18-0243.1, 2019. 